\title{
CHANGES IN THE TREATMENT OF ISCHAEMIC HEART DISEASE
}

Géza Lupkovics MD.

PhD Thesis

$2^{\text {nd }}$ Department of Internal Medicine and Cardiological Center Albert Szent-Györgyi Clinical Center University of Szeged Faculty of Medicine

Supervisor: Prof. Tamás Forster MD, PhD, DSc

Szeged

2011. 


\section{PUBLICATIONS RELATED TO THE SUBJECT OF THE THESIS}

Papers:

I. Mester J., Kósa I., Lupkovics G., Gruber N., Lázár M., Kovács G, Csernay L. Prospective evaluation of thallium-201 reinjection in single-vessel coronary patients undergoing coronary bypass surgery. Eur J Nucl Med 1993; 20: 213-218. IF: 1.832

II. Lupkovics G., Kenéz A., Németh Z., Motyovszki Á., Takács I., Papp E. Experience with Endeavor stent implantations. Coronary Artery Dis. 2008;19 (6): 421-423. IF: 1.556

III. Papp E., Lupkovics G. Strategies for the treatment of acute coronary syndromes. Present and future. Magyar Belorv Arch. 2008; 61, 356-360.

IV. Kenéz A., Németh Z., Motyovszki Á., Takács I., Lupkovics G. Our experience with Endeavor stent implantations. Cardiologia Hungarica. 2008; 38: 217-220.

V. Lupkovics G., Motyovszki A., Németh Z., Takács I., Kenéz A., Burkali B., Menyhárt I. Mortality rate of acute heart attack patients in Zalaegerszeg micro-region. Results of the first Hungarian 24 hour acute myocardial infarction intervention care unit. Orv Hetil 2010; 151(14): 565-571.

VI. Lupkovics G., Motyovszki A., Németh Z., Takács I., Kenéz A., Burkali B., Menyhárt I. Mortality rate of acute heart attack patients in Zalaegerszeg micro-region. Results of the first Hungarian 24 hour acute myocardial infarction intervention care unit. Clin Exp Med J 2010; 4: 1-9. 


\section{PUBLICATIONS NOT RELATED TO THE SUBJECT OF THE THESIS}

\section{Book chapters:}

1. Lupkovics G. Diagnostic and therapeautic recommendations for cardiac conditions. The guidelines of the College of Cardiology. Guide to Cardiology, 2002.

2. Papp E., Lupkovics G., Késmárky G., Tóth K. Characteristics of the restenosis In: Császár A. (Ed). Atherosclerosis - Theories - Clinical aspects. Medicina Publisher Ltd., Budapest, 130-138, 2010.

\section{Papers:}

1. Gaál T., Lupkovics G., Kertész E., Katona M. The significance of pulmonary balloon valvuloplasty in the cases of double outlet right ventricle that coincide with pulmonary stenosis. Card Hung, 1992; 21: 2.

2. Lupkovics G., Rudas L. Comparison of invasive and non-invasive measuring of blood pressure in patients following open heart surgery. Orv Hetil 1993; 134. 20332035.

3. Apró D., Lupkovics G., Mezey B. The role of transesophageal echocardiography in the detection of coronary anomalies and anatomical variations. Orv Hetil 1998; 139: 2203-2206.

4. Apró D., Motyovszki Á., Lupkovics G., Németh Z., Takács I., Mezey B. Detection of left main coronary artery stenosis by transesophageal echocardiography: sensitivity, specificity and safety. Supplement to Cardiology 1998; 7.

5. Apró D., Motyovszki Á., Lupkovics G., Németh Z., Takács I., Mezey B. Detection of significant left main coronary artery stenosis by transesophageal echocardiography: feasibility, sensitivity and specificity. Polish Heart J 1998; 49.

6. Apró D., Lupkovics G., Mezey B. The acute ischaemic syndrome from the point of view of the interventional cardiologist. Medical Education 1999; 3-4. 
7. Alotti N., Simon J., Lupkovics G., Kovács I., Puskás T. Successful surgical treatment of ruptured left ventricular aneurysm. Orv Hetil. 2000; 26; 141(13): 675677.

8. Molnár F., Lupkovics G., Ungi I. Revolutionary development in interventional cardiology: Cypher drug eluting stent. Medical. Management 2002; 3: 72-73.

9. Lupkovics G. The treatment of acute myocardial infarction with ST-segment elevations with primary PCI. Commentary. Journal of the American College of Cardiology (Hungarian Edition) 2002; 2.

10. Lupkovics G. In-stent restenosis: treatment or prevention. Journal of the American College of Cardiology (Hungarian Edition) 2003; 2.

11. Kisfali P., Mohás M., Maász A., Hadarits F., Markó L., Oroszlán T., Bagosi Z., Bujtor Z., Lupkovics G., Gasztonyi B., Wittmann I., Melegh B. Examination of apolipoprotein A5 gene IVS3+476A and 159C allele variants in metabolic syndrome patients. Magyar Belorv Arch. 2008, 123-127.

12. Jobbágy Á., Csordás P., Mersich A., Lupkovics G., Sztaniszláv Á. Blood pressure monitoring at home. Information Technology and Management in Health Care VII. 2008; 36-40.

13. Pusch G., Fehér G., Koltai K., Tibold A., Gasztonyi B., Fehér A., Papp E., Lupkovics G., Szapáry L. Aspirin resistance: focus on clinical endpoints (review). J. Cardiovasc. Pharmacol., 2008; 52, 475-484. IF: 2.023

14. Fehér G., Fehér A., Pusch G., Lupkovics G., Szapáry L., Papp E. The genetics of antiplatelet drug resistance (review). Clinical Genetics. 2009; 1, 1-18. IF: 3.181

15. Steinbeck G., Andresen D., Seidl K., Brachmann J., Hoffmann E., Wojciechowski D., Kornacewicz-Jach Z., Sredniawa B., Lupkovics G., Hofgärtner F., Lubinski A., Rosenqvist M., Habets A., Wegscheider K., Senges J.; IRIS Investigators. Defibrillator implantation early after myocardial infarction. $\mathrm{N}$ Engl $\mathrm{J}$ Med. 2009;361(15):1427-1436. IF: 47.050

Impact factor: $\mathbf{5 5 , 6 4 2}$ 


\section{Multicenter clinical studies:}

1. Antman E., Cooper H., Domanski M., Feinstein S., Gresh B., Gibler W.B., Haigney M., Hochman J., McKinlay S., Norman J., Opie L., Rogers W., Rosenberg Y., Woods K. Early administration of intravenous magnesium to high-risk patients with acute mycardial infarction in the Magnesium in Coronares (MAGIC) Trial: a randomised controlled trial. Lancet 2002; 360: 1189-1196. IF: 15.397

2. Blazing M.A., de Lemos J.A., White H.D., Fox K.A., Verheugt F.W., Ardissino D., DiBattiste P.M., Palmisano J., Bilheimer D.W., Snapinn S.M., Ramsey K.E., Gardner L.H., Hasselblad V., Pfeffer M.A., Lewis E.F., Braunwald E., Califf R.M. Safety and efficacy of enoxapariene vs unfractioned heparin in patients with nonST-segment elevation acute coronary syndromes who receive tirofiban and aspirin a randomized controlled trial. JAMA. 2004; 292: 55-64. IF: 24.831

3. Van de Werf F., Ross A., Armstrong P., Granger C Group Author(s) ASSENT-4 PCI Investigators. Primary versus tenecteplase - facilitated percutaneous coronary intervention in patients with ST - segment elevation acute myocardial infarction (ASSENT-4 PCI): randomised trial. Lancet, 2006; 367: 569-578. IF: 25.80

4. Yusuf S., Mehta S.R., Chrolavicius S., Afzal R., Pogue J., Granger C.B., Budaj A., Peters R.J.G., Bassand J.P., Wallentin L., Joyner C., Fox K.A. Comparison of fondaparinux and enoxaparine in acute coronary syndromes. N Engl J Med 2006; 354:1464-1476. IF: $\mathbf{5 1 . 2 9 6}$

5. Yusuf S., Mehta S.R., Chrolavicius S., Afzal R., Pogue J., Granger C.B., Budaj A., Peters R.J.G., Bassand J.P., Wallentin L., Joyner C., Fox K.A. Effects of fondaparinux on mortality and reinfarction in patients with acute ST-segment elevation myocardial infarction. JAMA. 2006; 295:1519-1530. IF: 23.175

6. Alexander J.H., Reynolds H.R., Stebbins A.L., Dzavik V., Harrington R.A., Van de Werf F., Hochman J.S. Effect of tilarginine acetate in patints with acute myocardial infarction and cardiogenic shock. The TRIUMPH randomized controlled trial. JAMA. 2007; 297:1657-1666. IF: 25.547

7. Hricak V., Leizorovicz A. on behalf SAFRAX investigators. Once-daily nadroparin versus twice-daily nadroparin in the treatment of patients with acute coronary syndromes. Cardiol. 2007; 16(4):158-160.

8. Fox K., Ford I., Steg P.G., Tendera M., Ferrari R.; BEAUTIFUL Investigators. Ivabradine for patients with stable coronary artery disease and left-ventricular 
systolic dysfunction (BEAUTIFUL): a randomised, double-blind, placebocontrolled trial. Lancet. 2008; 372 (9641): 807-816. IF: 17.490

9. Ferrari R., Ford I., Fox K., Steg P.G., Tendera M. The BEAUTIFUL study: randomized trial of ivabradine in patients with stable coronary artery disease and left ventricular systolic dysfunction - baseline characteristics of the study population. Beautiful Study Group. Int J Cardiology. 2008; 110(4):271-282. IF: 2.918

10. Schwartz G.G., Olsson A.G., Ballantyne C.M., Barter P.J., Holme I.M., Kallend D., Leiter L.A., Leitersdorf E., McMurray J.J., Shah P.K., Tardif J.C., Chaitman B.R., Duttlinger-Maddux R., Mathieson J. dal-OUTCOMES Committees and Investigators. Rationale and design of the dal-OUTCOMES trial: efficacy and safety of dalcetrapib in patients with recent acute coronary syndrome. Am Heart J. 2009; 158(6):896-901. IF: 4.357

11. Wallentin L., Becker R.C., Budaj A., Cannon C.P., Emanuelsson H., Held C., Horrow J., Husted S., James S., Katus H., Mahaffey K.W., Scirica B.M., Skene A., Steg P.G., Storey R.F., Harrington R.A.; PLATO Investigators, Freij A, Thorsén M. Ticagrelor versus clopidogrel in patients with acute coronary syndromes. N Engl J Med. 2009; 361(11): 1045-1057. IF: 47.050

12. Mega J.L, Braunwald E., Mohanavelu S., Burton P., Poulter R., Misselwitz F., Hricak V., Barnathan E.S., Bordes P., Witkowski A., Markov V., Oppenheimer L., Gibson C.M; ATLAS ACS-TIMI 46 study group. Rivaroxaban versus placebo in patients with acute coronary syndromes (ATLAS ACS-TIMI 46): a randomised, double-blind, phase II trial. Lancet. 2009; 374 (9683): 29-38. IF: 30.758

13. Giugliano R.P., White J.A., Bode C., Armstrong P.W., Montalescot G., Lewis B.S., van 't Hof A., Berdan L.G., Lee K.L., Strony J.T., Hildemann S., Veltri E., Van de Werf F., Braunwald E., Harrington R.A., Califf R.M., Newby L.K; EARLY ACS Investigators. Early versus delayed, provisional eptifibatide in acute coronary syndromes. N Engl J Med. 2009; 360 (21): 2176-2190. IF: 47.050

14. Jones R.H., Velazquez E.J., Michler R.E., Sopko G., Oh J.K., O'Connor C.M., Hill J.A., Menicanti L., Sadowski Z., Desvigne-Nickens P., Rouleau J.L., Lee K.L.; STICH Hypothesis 2 Investigators. Coronary bypass surgery with or without surgical ventricular reconstruction. N Engl J Med. 2009; 360(17): 1705-1717. IF: 47.050 
15. Lablanche J.M., Leone A., Merkely B., Morais J., Alonso J., Santini M., Eha J., Demil N., Licour M., Tardif J.C.; CENTAURUS investigators. Comparison of the efficacy of rosuvastatin versus atorvastatin in reducing apolipoprotein B/apolipoprotein A-1 ratio in patients with acute coronary syndrome: results of the CENTAURUS study. Arch Cardiovasc Dis. 2010; 103(3):160-169. IF: 0.663 .

16. Weatherley B.D., Cotter G., Dittrich H.C., DeLucca P., Mansoor G.A., Bloomfield D.M., Ponikowski P., O'Connor C.M., Metra M., Massie B.M.; PROTECT Steering Committee, Investigators, and Coordinators. Design and rationale of the PROTECT study: a placebo-controlled randomized study of the selective A1 adenosine receptor antagonist rolofylline for patients hospitalized with acute decompensated heart failure and volume overload to assess treatment effect on congestion and renal function. J Card Fail. 2010; 16(1):25-35. IF: 3.254 (2009) 


\section{Table of contents}

$\begin{array}{lr}\text { Abbreviations } & 9\end{array}$

Introduction 11

$\begin{array}{ll}\text { Background } & 12\end{array}$

1. The definition of acute myocardial infarction $\quad 12$

2. The pathogenesis of ST-segment elevation acute myocardial infarction $\quad 13$

3. The natural history of STEMI 14

4. Initial diagnosis and early risk stratification $\quad 15$

$\begin{array}{ll}\text { 5. Restoring coronary flow and myocardial tissue reperfusion } & 17\end{array}$

$\begin{array}{ll}\text { 6. Percutaneous coronary interventions } & 17\end{array}$

$\begin{array}{ll}\text { Primary PCI and delay times } & 17\end{array}$

$\begin{array}{ll}\text { Facilitated PCI } & 19\end{array}$

$\begin{array}{ll}\text { Rescue PCI } & 20\end{array}$

$\begin{array}{ll}7 . \text { Coronary bypass surgery } & 20\end{array}$

8. Assessment of myocardial viability 21

Aims of the investigation $\quad 22$

I. Prospective evaluation of thallium-201 reinjection in single-vessel coronary patients undergoing coronary bypass surgery 23

Introduction 23

Aims 23

Patients and methods 23

Results 25

Conclusion 31

II. Changes in the mortality of acute myocardial infarction in the area of Zalaegerszeg. Effects of the first 24 hour ST-elevation acute myocardial infarction intervention service in Hungary 33

Introduction 33

Aims 33

Patients and methods 33

Results 34

$\begin{array}{ll}\text { Conclusion } & 40\end{array}$ 
III. Experience with Endeavor stent implantations 42

Introduction $\quad 42$

Aims $\quad 42$

Patients and methods $\quad 42$

Results 43

Conclusion 45

Discussion of the dissertation $\quad 47$

$\begin{array}{ll}\text { Acknowledgments } & 48\end{array}$

$\begin{array}{ll}\text { References } & 49\end{array}$ 


\section{Abbreviations}

ACC/AHA American College of Cardiology/American Heart Association

ACS acute coronary syndrome

ASA acetylsalicylic acid

BMS bare metal stent

CABG coronary artery bypass graft

CRP C-reactive protein

CTO chronic total occlusions

DES drug eluting stent

ECG electrocardiographic/electrocardiogram

EMS emergency medical system

ESC European Society of Cardiology

FMC first medical contact

GP glycoprotein

h hour

ICD implantable cardioverter-defibrillator

ISR in-stent restenosis

LAD left anterior descending artery

LIMA left internal mammary artery

LM left main

LV left ventricular

MACE major acute cardiac event

min minute

MRI magnetic resonance imaging

OM obtuse marginal

PCI percutaneous coronary intervention

PET positron emission tomography

PTCA percutaneous transluminal coronary angioplasty seconds

SMR standardised mortality rate

SPECT single-photon emission computed tomography 
STEMI acute ST-segment elevation myocardial infarction

${ }^{201} \mathbf{T l} \quad$ thallium-201

TIMI thrombolysis in myocardial infarction

TLR target lesion revascularization

TVF target vessel failure

RCX ramus circumflexus artery

RCA right coronary artery

SVG saphena venous graft 


\section{Introduction}

Coronary artery diseases and mortality are a major health problem in the industrialised western countries and that is true for Hungary as well. Myocardial infarction has become more frequent mainly in developed countries over the past decades.

Besides the modern pharmacological treatment interventional procedures (percutaneous transluminal coronary angioplasty, percutaneous coronary intervention, stenting, intraaortic ballon pump, resyncronising therapy, implantable cardioverter-defibrillator) the quality of life of the patients and the mortality data were improved.

We would like to demonstrate the development, the present status and perspectives of interventional cardiology in Zala County Hospital, Zalaegerszeg 


\section{Background}

\section{The definition of acute myocardial infarction}

The ineffective blood supply of the myocardium is caused by the stenosis of the coronaries on the basis of atherosclerosis. Myocardial ischemia is presented as stable angina pectoris or acute coronary syndromes (ACS).

Acute myocardial infarction can be defined from a number of different perspectives related to clinical, electrocardiographic (ECG), biochemical, and pathological characteristics (1).

The European Society of Cardiology's (ESC) present guidelines pertain to patients presenting with ischaemic symptoms and persistent ST-segment elevation on the ECG (STEMI). The great majority of these patients will show a typical rise of biomarkers of myocardial necrosis and progress to Q-wave myocardial infarction.

\begin{tabular}{|c|l|}
\hline \multicolumn{1}{|c|}{ Classes of recomendations } & \multicolumn{1}{c|}{ Definition } \\
\hline Class I & $\begin{array}{l}\text { Evidence and/or general agreement that a given } \\
\text { treatment or procedure is beneficial, useful, } \\
\text { effective. }\end{array}$ \\
\hline Class II & $\begin{array}{l}\text { Conflicting evidence and/or a divergence of } \\
\text { opinion about the usefulness/efficacy of the given } \\
\text { treatment or procedure. }\end{array}$ \\
\hline Class IIa & $\begin{array}{l}\text { Weight of evidence/opinion is in favour of } \\
\text { usefulness/efficacy. }\end{array}$ \\
\hline Class IIb & $\begin{array}{l}\text { Usefulness/efficacy is less well established by } \\
\text { evidence/opinion. }\end{array}$ \\
\hline Class III & $\begin{array}{l}\text { Evidence or general agreement that the given } \\
\text { treatment or procedure is not useful/effective, and } \\
\text { in some cases may be harmful. }\end{array}$ \\
\hline
\end{tabular}

Table 1. Classes of recommendations 


\begin{tabular}{|l|l|}
\hline Level of Evidence A & $\begin{array}{l}\text { Data derived from multiple randomized clinical trials } \\
\text { or meta-analyses. }\end{array}$ \\
\hline Level of Evidence B & $\begin{array}{l}\text { Data derived from a single randomized clinical trial or } \\
\text { large non-randomized studies. }\end{array}$ \\
\hline Level of Evidence C & $\begin{array}{l}\text { Consensus of opinion of the experts and/or small } \\
\text { studies, retrospective studies, registries. }\end{array}$ \\
\hline
\end{tabular}

Table 2. Levels of evidence

\section{The pathogenesis of ST-segment elevation acute myocardial infarction}

Most cases of STEMI are caused by an occlusion of a major coronary artery. Coronary occlusion and reduction in coronary blood flow are usually due to physical disruption of an atherosclerotic plaque with subsequent formation of an occluding thrombus. Concomitant coronary vasoconstriction and microembolization may be involved to some extent. Less commonly a thrombus may form from a superficial erosion of the endothelial surface. The risk of plaque disruption depends on plaque composition and vulnerability (plaque type) and degree of stenosis (plaque size) (2).

As many as three-quarters of all infarct-related thrombi appear to evolve over plaques causing only mild to moderate stenosis. Even portions of the coronary arterial tree that appear normal by angiographic criteria often harbour a substantial burden of atherosclerosis. In particular, plaques with substantial outward remodelling, or 'compensatory enlargement', can have thin, fibrous caps and large lipid pools without encroachment of the lumen (3).

However, severe stenoses are as likely to undergo plaque events leading to infarction as are mild ones (4).

There is frequently a delay (up to 2 weeks) between the rupture of a plaque and its clinical consequences (5).

Inflammation plays an important role in plaque instability, and therefore in the pathogenesis of acute coronary syndromes. Circulating levels of inflammatory markers such as C-reactive protein (CRP) and interleukin-6 correlate with the clinical course and outcome of an acute coronary syndrome $(6,7,8)$. 
The circadian variation of STEMI with a higher incidence in the early morning hours can be explained by the combination of b-adrenergic stimulation (increased vascular tone and blood pressure), hypercoagulability of the blood, and hyperreactivity of platelets. Activities associated with increased sympathetic stimulation and vasoconstriction, such as physical or emotional stress, may also trigger plaque disruption and coronary thrombosis (9).

Myocardial necrosis caused by complete coronary artery occlusion begins to develop after 15-30 min of severe ischaemia (no forward or collateral flow) and progresses from the subendocardium to the subepicardium in a time-dependent fashion ("the wave-front phenomenon'). Reperfusion, including recruitment of collaterals, may save myocardium at risk from undergoing necrosis, and subcritical but persistent forward flow may extend the time window for achieving myocardial salvage.

The thrombotic response to plaque disruption is dynamic: thrombosis and clot lysis, often associated with vasospasm, occur simultaneously, and may cause intermittent flow obstruction and distal embolization (10).

The absence of complete healing of an ageing plaque (incomplete re-endothelialization) and thrombus formation play an important role in the occurrence of sudden occlusive coronary thrombosis. In $\sim 25-30 \%$ of patients undergoing primary percutaneous intervention (PCI), initial angiography shows a patent infarct-related artery (11).

In these patients, it is presumed that spontaneous, endogenous lysis occurred before angiography. Both platelets and fibrin are involved in the evolution of a persisting coronary thrombus. Whereas platelet adhesion and aggregation initiate mural thrombus formation, fibrin is important for the subsequent stabilization of the early and fragile platelet thrombus.

\section{The natural history of STEMI}

The true natural history of STEMI is hard to establish for a number of reasons: the common occurrence of silent infarction, the frequency of sudden death outside the hospital, and the varying methods and definitions used in the diagnosis of the condition. Community studies have consistently shown that the overall case fatality rate of patients with presumed myocardial infarction or acute coronary syndrome in the first month is $50 \%$, and of these deaths about half occur within the first $2 \mathrm{~h}$ (12). 
This high initial mortality seems to have altered little over the last years in contrast to hospital mortality (13).

In contrast to community mortality, there has been a profound fall in the fatality of patients treated in hospital. Prior to the introduction of coronary care units in the $1960 \mathrm{~s}$, the in-hospital mortality seems to have averaged $\sim 25-30 \%$. A systematic review of mortality studies in the pre-reperfusion era of the mid-1980s showed an average inhospital fatality of $\sim 16 \%$. With the widespread use of coronary interventions, fibrinolytic agents, antithrombotic therapy, and secondary prevention, the overall 1month mortality has since been reduced to $4-6 \%$, at least in those who participated in the latest randomized large-scale trials and qualified for fibrinolysis and/or coronary interventions $(14,15)$.

Optimal treatment of STEMI should be based on the implementation of an emergency medical system (EMS) supervising a network between hospitals with various levels of technology, connected by an efficient ambulance (or helicopter) service

The main features of such a network are: clear definition of geographical areas of interest, shared protocols based on risk stratification, and transportation with appropriately equipped and staffed ambulances (or helicopters). A well-functioning regional system of care based on pre-hospital diagnosis and triage and fast transport to the most appropriate facility is key to the success of the treatment, and significantly improves outcome $(16,17)$.

\section{Initial diagnosis and early risk stratification}

Rapid diagnosis and early risk stratification of patients presenting with acute chest pain are important to identify patients in whom early interventions can improve outcome. On the other hand, when the diagnosis of STEMI has been ruled out, attention can be focused on the detection of other cardiac or non-cardiac causes of the presenting symptoms such as aortic dissection, pulmonary embolism, and pericarditis. The diagnosis of STEMI is usually based on the history of chest pain/discomfort lasting for 10-20 min or more (not responding fully to nitroglycerine). Other locations such as epigastric or interscapular are possible. Important clues are a previous history of 
coronary artery disease and radiation of the pain to the neck, lower jaw, or left arm. The pain may not be severe and, in the elderly particularly, other presentations such as fatigue, dyspnoea, faintness, or syncope are common. There are no individual physical signs diagnostic of STEMI, but many patients have evidence of autonomic nervous system activation (pallor, sweating) and either hypotension or a narrow pulse pressure. Features may also include irregularities of the pulse, bradycardia or tachycardia, a third heart sound, and basal rales. An ECG should be obtained as soon as possible. Even at an early stage, the ECG is seldom normal.

In the case of STEMI or new or presumed new left bundle-branch block, reperfusion therapy needs to be given, and measures to initiate this treatment must be taken as soon as possible.

However, the ECG can be equivocal in the early hours, and even in proven infarction it may never show the classical features of ST-segment elevation and new Q-waves. Repeated ECG recordings should be obtained and, when possible, the current ECG should be compared with previous records. Additional recordings of lead V7-V8 or V4R are helpful to make the diagnosis in selected cases (true posterior infarction or right ventricular infarction, respectively). ECG monitoring should be initiated as soon as possible in all patients to detect life-threatening arrhythmias. In patients with slowly evolving or stuttering myocardial infarction, serial ECGs should be taken to detect evolving infarction. Blood sampling for serum markers of necrosis is routinely done in the acute phase, but one should not wait for the results to initiate reperfusion treatment. The finding of elevated markers of necrosis may sometimes be helpful in deciding to perform coronary angiography (e.g. in patients with left bundle-branch block).

Two-dimensional echocardiography has become a useful bedside technique in the triage of patients with acute chest pain. Regional wall motion abnormalities occur within seconds after coronary occlusion, well before necrosis. However, wall motion abnormalities are not specific for STEMI and may be due to ischaemia or an old infarction. Two-dimensional echocardiography is of particular value when the diagnosis of STEMI is uncertain, and other causes of chest pain such as acute aortic dissection, pericardial effusion, or pulmonary embolism are being considered. The performance of echocardiography should not delay the initiation of treatment. The absence of wall motion abnormalities excludes major myocardial ischaemia.

Older age, higher Killip class, elevated heart rate, lower systolic blood pressure, and anterior location of the infarct have been identified as the most important independent 
predictors of early mortality in clinical trials (18) and registries (19, 20). These characteristics contain most of the prognostic information in the clinical data available at the time of the first medical contact. Other independent predictors are previous infarction, height, time to treatment, diabetes, weight, and smoking status (18).

\section{Restoring coronary flow and myocardial tissue reperfusion}

For patients with the clinical presentation of STEMI within $12 \mathrm{~h}$ following symptom onset and with persistent ST-segment elevation or new or presumed new left bundlebranch block, early mechanical (PCI) or pharmacological reperfusion should be performed. There is general agreement that reperfusion therapy (primary PCI) should be considered if there is clinical and/or electrocardiographic evidence of ongoing ischaemia, even if, according to the patient, symptoms started $>12 \mathrm{~h}$ before as the exact onset of symptoms is often unclear. However, there is no consensus as to whether PCI is also beneficial in patients presenting $>12 \mathrm{~h}$ from symptom onset in the absence of clinical and/or electrocardiographic evidence of ongoing ischaemia. In a randomized study in STEMI patients presenting without persisting symptoms between 12 and $48 \mathrm{~h}$ after symptom onset $(n=347)$, PCI was associated with significant myocardial salvage, lending some support to an invasive strategy in these patients, but clinical outcomes were no better (21). In the OAT trial including 2166 stable patients with an occluded infarct-related vessel 3 to 28 calendar days after symptom onset, PCI did not improve clinical outcome (22), including in the subgroup of 331 patients randomized between 24 and $72 \mathrm{~h}$ after onset of infarction (23).

\section{Percutaneous coronary interventions}

The role of PCIs during the early hours of STEMI can be divided into primary PCI, PCI combined with pharmacological reperfusion therapy (facilitated PCI), and 'rescue PCI' after failed pharmacological reperfusion.

\section{Primary PCI and delay times}

Primary PCI is defined as angioplasty and/or stenting without prior or concomitant 
fibrinolytic therapy, and is the preferred therapeutic option when it can be performed expeditiously by an experienced team. An experienced team includes not only interventional cardiologists but also skilled supporting staff.

This means that only hospitals with an established interventional cardiology programme (24 h/7 days) should use primary PCI as a routine treatment option for patients presenting with the symptoms and signs of STEMI. Lower mortality rates among patients undergoing primary PCI are observed in centres with a high volume of PCI procedures $(24,25)$.

Primary PCI is effective in securing and maintaining coronary artery patency and avoids some of the bleeding risks of fibrinolysis. Randomized clinical trials comparing timely performed primary PCI with in-hospital fibrinolytic therapy in high-volume, experienced centres have shown more effective restoration of patency, less reocclusion, improved residual left ventricular (LV), function and better clinical outcome with primary PCI (26).

Routine coronary stent implantation in patients with STEMI decreases the need for target vessel revascularization but is not associated with significant reductions in death or reinfarction rates $(27,28)$ when compared with primary angioplasty. In addition, several randomized clinical trials with medium-term follow-up, including patients with STEMI, have shown that drug-eluting stents reduce the risk of reintervention compared with bare metal stents, without having a significant impact on the risk of stent thrombosis, recurrent myocardial infarction, and death $(29,30,30)$.

As for other clinical presentations of coronary artery disease, long-term data on the efficacy and safety of drug-eluting stents in patients with STEMI are still needed.

Both randomized studies and registries have indicated that long delay times to primary PCI are associated with a worse clinical outcome $(32,33)$.

Several delay times can be defined: time from symptom onset to first medical contact (FMC), time from FMC to arrival in cath lab, time from FMC to sheath insertion, time from FMC to balloon inflation. The 'PCI-related delay time' is the theoretical difference between the time of FMC to balloon inflation minus the time from FMC to start of fibrinolytic therapy (= 'door-to-balloon' minus 'door-to-needle'). The extent to which the PCI-related time delay diminishes the advantages of PCI over fibrinolysis has been the subject of many analyses and debates. Because no specifically designed study has addressed this issue, caution is needed when interpreting the results of these post 
hoc analyses. From randomized trials it was calculated that the PCI-related time delay that may mitigate the benefit of the mechanical intervention varies between 60 (34) and 110 min (35) depending on the fibrinolytic used (36).

In another analysis of these trials, a benefit of primary PCI over fibrinolytic therapy up to a PCI-related delay of 120 min was calculated (37).

In 192509 patients included in the NRMI 2-4 registry (38) the mean PCI-related time delay where mortality rates of the two reperfusion strategies were equal was calculated at $114 \mathrm{~min}$. This study also indicated that this time delay varied considerably according to age, symptom duration, and infarct location: from $<1 \mathrm{~h}$ for an anterior infarction in a patient $<65$ years presenting $<2 \mathrm{~h}$ after symptom onset, to almost $3 \mathrm{~h}$ for a non-anterior infarction in a patient $>65$ years presenting $>2 \mathrm{~h}$ after symptom onset. Although these results were derived from a post hoc analysis of a registry and reported delay times are sometimes inaccurate, this study suggests that an individualized rather than a uniform approach for selecting the optimal reperfusion modality could be more appropriate when PCI cannot be performed within a short delay.

Taking into account the studies and registries mentioned above, primary PCI (balloon inflation) should be performed within $2 \mathrm{~h}$ after FMC in all cases. In patients presenting early with a large amount of myocardium at risk, the delay should be shorter.

Although no specific studies have been performed, a maximum delay of only 90 min after FMC seems to be a reasonable recommendation in these patients. Patients with contraindications to fibrinolytic therapy have a higher morbidity and mortality than those eligible for this therapy. Primary PCI can be performed with success in these patients (39). Primary PCI is the preferred treatment for patients in shock (40).

Except for patients in cardiogenic shock, only the culprit lesion should be dilated in the acute setting. Complete revascularization of the non-culprit lesions may be performed at a later time point depending on the remaining ischaemia.

\section{Facilitated PCI}

Facilitated PCI is defined as a pharmacological reperfusion treatment delivered prior to a planned PCI, in order to bridge the PCI-related time delay. Full-dose lytic therapy, half-dose lytic therapy with a glycoprotein (GP)IIb/IIIa inhibitor and GPIIb/IIIa inhibitor alone have been tested for this indication. There is no evidence of a significant clinical benefit with any of these agents $(11,15,41,42)$.

In spite of the fact that pre-PCI patency rates were higher with lytic-based treatments, 
no mortality benefit but more bleeding complications were observed. The pre-PCI patency rates with upfront abciximab or high-bolus dose tirofiban alone were not higher than with placebo. Facilitated PCI as it has been tested in these trials cannot be recommended.

\section{Rescue PCI}

Rescue PCI is defined as PCI performed on a coronary artery which remains occluded despite fibrinolytic therapy. The non-invasive identification of failed fibrinolysis remains a challenging issue, but $<50 \%$ ST-segment resolution in the lead(s) with the highest ST-segment elevations 60-90 $\mathrm{min}$ after start of fibrinolytic therapy has increasingly been used as a surrogate. Rescue PCI has been shown to be feasible and relatively safe. In a randomized study of 427 patients (REACT), the event-free survival at 6 months after failed fibrinolysis was significantly higher with rescue PCI than with repeated administration of a fibrinolytic agent or conservative treatment (43).

A recent meta-analysis, including REACT, showed that rescue PCI is associated with a significant reduction in heart failure and reinfarction and a trend towards lower allcause mortality when compared with a conservative strategy, at the cost, however, of an increased risk of stroke and bleeding complications (44).

Rescue PCI should be considered when there is evidence of failed fibrinolysis based on clinical signs and insufficient ST-segment resolution $(<50 \%)$, if there is clinical or ECG evidence of a large infarct, and if the procedure can be performed within a reasonable time delay (up to $12 \mathrm{~h}$ after onset of symptoms).

\section{Coronary bypass surgery}

The number of patients who need a coronary artery bypass graft (CABG) in the acute phase is limited, but CABG may be indicated after failed PCI, when coronary occlusion is not amenable for PCI, presence of refractory symptoms after PCI, cardiogenic shock, or mechanical complications such as ventricular rupture, acute mitral regurgitation, or ventricular septal defect $(45,46)$.

If a patient requires emergency stenting of a culprit lesion in the setting of a STEMI but further surgical revascularization is already predictable in the near future, the use of bare metal stents instead of drug-eluting stents should be recommended to avoid the 
problem of acute perioperative stent thrombosis. In patients with an indication for CABG, e.g. multivessel disease, it is recommended to treat the infarct-related lesion by PCI and to perform CABG later in more stable conditions.

\section{Assessment of myocardial viability}

LV dysfunction after STEMI may be due to necrosis, to stunning of viable myocardium remaining in the infarct territory, to hibernation of viable myocardium, or to a combination of all three (47).

Simple stunning should usually recover within 2 weeks of the acute ischaemic insult if reperfusion has been established, but, if ischaemic episodes persist, recurrent stunning may become hibernate and require revascularization for recovery of function. These concepts are of most relevance in the patient with severely impaired LV function after STEMI when the need for revascularization to improve function is considered.

Several diagnostic techniques can detect myocardial viability. Of these, conventional myocardial perfusion scintigraphy (with thallium-201- or technetium-99 m-labelled agents) or stress echocardiography (usually with dobutamine) are most widely available, whereas magnetic resonance imaging (MRI) and positron emission tomography (PET) are less available. 


\section{Aims of the investigations}

In our investigations we aimed to find the answer to the following questions:

1. The aim of our first study was to examine myocardial perfusion changes with the use of internal mammary artery graft in patients who underwent cardiac surgery.

2. The aim of our second study was to examine if the treatment of STEMI patients by primary PCI changes mortality rate in STEMI patients.

3. The aim of our third study was to examine the efficacy of drug-eluting stents for ischaemic heart disease. 


\section{Prospective evaluation of thallium-201 reinjection in single-vessel coronary patients undergoing coronary bypass surgery}

\section{Introduction:}

A possibility for enhancement of the sensitivity of thallium-201 $\left({ }^{2 \mathrm{O}} \mathrm{Tl}\right)$ myocardial perfusion scintigraphy in the detection of injured but viable myocardium is the reinjection of a half dose of ${ }^{2 \mathrm{O}} \mathrm{Tl}$ immediately after the resting study. This method offers better counting statistics than 24-to 72-h delayed imaging, furthermore, the investigation can be completed within 1 day, which is more practicable for the patient $(48,49,50)$.

It is of special interest to establish whether this modified technique of myocardial perfusion scintigraphy is suitable for the identification of reversible injured myocardium before revascularization surgery and for the prediction of the recovery of nutritive perfusion (51).

\footnotetext{
Aims:

We have investigated the predictive value of ${ }^{2 \mathrm{O}} \mathrm{Tl}$ reinjection in a homogeneous patient group with single-vessel coronary disease.

The aim of the study was to clarify whether ${ }^{2 \mathrm{O}} \mathrm{Tl}$ reinjection method is suitable for the prediction of myocardial perfusion soon after successful coronary bypass grafting.
}

\section{Patients and methods:}

These studies were carried out at the University of Szeged Faculty of Medicine (collaboration with Department of Nuclear Medicine, Department of Cardiac Surgery and 2nd Medical Clinic, Albert Szent-Györgyi Medical University).

Twenty-two patients ( 5 females, 17 males, mean age $51.9 \pm 9.8$ years, range 39-69 years) with single-vessel left anterior descending (LAD) coronary artery disease were investigated before and after coronary bypass surgery. Five patients had anamnestic non-Q and two patients Q-wave anterior myocardial infarction. 
Coronary angiography documented LAD coronary occlusion in five patients, and subtotal LAD lesions in 17 patients. The other main coronary vessels were without significant narrowing.

During coronary bypass surgery the internal mammary artery was used for revascularization of the LAD territory. None of the patients had documented perioperative myocardial infarction.

Investigation of myocardial perfusion. Dipyridamole stress myocardial perfusion scintigraphy was performed, using SPECT, in each patient 4-10 days before and 14-25 days after bypass surgery.

Dipyridamole test. Patients were instructed to fast for at least $12 \mathrm{~h}$ and to avoid ingesting products containing caffeine for $24 \mathrm{~h}$ before the test. Oral theophylline, nitrates and calcium antagonists were discontinued $24 \mathrm{~h}$ before the investigation. The patients were placed in a supine position. A cannula was introduced into the antecubital vein. Twelve lead ECG and blood pressure were recorded at rest, and $0.56 \mathrm{mg}$ dipyridamole/kg body weight was then administered over $4 \mathrm{~min}$. At $6.5 \mathrm{~min}$ after the beginning of the test, $74 \mathrm{MBq}$ of ${ }^{2 \mathrm{Ol}} \mathrm{Tl}$ was injected intravenously, and washed with an additional $20 \mathrm{ml}$ of isotonic sodium chloride.

If the patient had angina during the test or there was at least a 3-mm ST segment shift $0.08 \mathrm{~s}$ after the $\mathrm{J}$ point, the test was discontinued and ${ }^{2 \mathrm{Ol}} \mathrm{Tl}$ was injected immediately. One minute after ${ }^{2 \mathrm{Ol}} \mathrm{Tl}$ injection, $240 \mathrm{mg}$ aminophylline was injected and, if necessary, nitroglycerine or nifedipine (Corinfar) was also given.

Single photon emission computed tomography imaging. SPECT was performed $10 \mathrm{~min}$ and $3 \mathrm{~h}$ after ${ }^{2 \mathrm{Ol}} \mathrm{Tl}$ injection. Thirty projection images were collected at $6^{\circ}$ intervals over $180^{\circ}$ from right anterior $45^{\circ}$ to left posterior $45^{\circ}$. Images were acquired for $40 \mathrm{~s}$ at a digital resolution of $64^{2}$, without zoom.

${ }^{2 O l} \mathrm{Tl}$ reinjection. Before bypass surgery and after completion of the redistribution study, $1 \mathrm{mCi}$ of ${ }^{2 \mathrm{Ol}} \mathrm{Tl}$ was injected. Repeated SPECT was performed $10 \mathrm{~min}$ and $1 \mathrm{~h}$ following reinjection. No reinjection was performed after surgery. 
Image reconstruction and display. The images were reconstructed to 1-pixel (6-mm) thick transaxial sections by filtered back projection, using a Hamming filter. After reorientation, for qualitative evaluation, the left ventricular myocardium was divided into four thick short-axis slices from the apex to the base. Over the left ventricular cavity, four equally thick verticallong-axis slices were also reconstructed and displayed.

Semiquantitative evaluation of myocardial perfusion. For semiquantitative evaluation of myocardial perfusion, two short-axis slices about $1.5 \mathrm{~cm}$ thick were considered, representing the mid-ventricular myocardium and the distal wall of the left ventricular cavity.

The perfusion of the apex was evaluated considering the vertical long-axis slices.

The radionuclide uptakes of ten myocardial segments supplied by the LAD coronary artery were scored. A five-grade defect severity scoring system was used. Normally perfused segments received a score of $\mathrm{O}$, minimally hypoperfused segments a score of 1 , moderately hypoperfused segments a score of 2 , definitely hypoperfused segments a score of 3 , and non-perfused segments a score of 4 .

For the characterization of overall myocardial perfusion, the scores were added. Scintigrams were considered abnormal if the overall score was 3 or greater. Two scintigrams were considered to be significantly different if the difference in overall Store was 2 or greater. A higher overall store in the 3-h redistribution study than in the stress study or, generally, a higher store in a second study than in the previous one, was considered to represent paradox redistribution.

\section{Results:}

\section{Left ventricular function}

Ventricular hypokinesia was proven by radionuclide ventriculography before surgery in 18 patients. On radionuclide ventriculography, the left ventricular ejection fraction lay in the range $33 \%-62 \%$ (mean $50.8 \% \pm 8.2 \%$ ).

After surgery, the left ventricular wall motion was normalized in seven patients, and improved in one patient. The postoperative left ventricular ejection fraction lay in the range $45 \%-74 \%$ (mean $56.2 \% \pm 10.1 \%$ ). 


\section{Dipyridamole test}

Before surgery, the complete dose of dipyridamole was administered in 19 of 22 patients. Dipyridamole infusion was interrupted after 3.5 instead of 4 min in three patients, due to severe chest pain in the 3rd minute of the stress.

Aminophylline was necessary in 13 patients; five of them received additional antianginal meditation (nitro-glycerine and/or nifedipine).

After surgery, the whole dose of dipyridamole was administered to all patients. No aminophylline or other drugs were given after stress.

\section{Haemodynamic data and ECG changes during stress}

The heart rate and systolic and diastolic blood pressure data are listed in Table 3. Before surgery, significant ischaemic. ECG changes were present in 4 of 22 patients; after surgery, no significant ECG changes were noted during stress. Before surgery, 14 patients had chest pain during stress (in 13 of them aminophylline was given); after surgery, one patient had an atypical feeling of chest discomfort at the end of stress.

\begin{tabular}{|l|l|l|l|}
\hline \multicolumn{2}{|c|}{ Heart rate } & \multicolumn{2}{c|}{ Blood pressure } \\
\hline Initial & $\mathrm{At}^{201} \mathrm{TI}$ inj & Initial & $\mathrm{At}^{201} \mathrm{TI}$ inj \\
\hline \multicolumn{3}{|c|}{ Before CABG } \\
\hline $77.3 \pm 14.7$ & $93.1 \pm 16.7$ & $\begin{array}{l}145.0 / 85.5 \\
\pm 20.4 / \pm 10.1\end{array}$ & $\begin{array}{l}137.3 / 84.5 \\
\pm 18.3 / \pm 8.6\end{array}$ \\
\hline \multicolumn{5}{|c|}{ After CABG } & $131.4 / 83.2$ \\
& & $135.2 / 81.8$ & $\pm 12.9 / \pm 9.3$ \\
\hline $96.6 \pm 11.0$ & $103.8 \pm 15.2$ & $\pm 12.2 / \pm 5.9$ & \\
\hline
\end{tabular}

Table 3. Changes in haemodynamic parameters during dipyridamole testing 
Myocardial perfusion during stress before surgery

A significant perfusion defect was seen on the preoperative stress scintigrams in 21 of 22 cases. The defect scores ranged from $\mathrm{O}$ to 28 , with a mean of 17.0 (Table 4).

In one patient, with $99 \%$ proximal LAD narrowing, the stress scintigram was normal. In this patient the dipyridamole infusion was interrupted after 3.5 min because of typical chest pain and a 2-mm descending ST depression on the ECG. The patient received 240 mg aminophylline, nifedipine and sublingual nitroglycerine.

\begin{tabular}{|c|c|c|c|c|c|}
\hline \multicolumn{4}{|c|}{ Before CABG } & \multicolumn{2}{|c|}{ After CABG } \\
\hline Stress & $3 \mathrm{~h}$ rest & $\begin{array}{l}10 \text { min } \\
\text { after } \\
\text { reinjection }\end{array}$ & $\begin{array}{l}60 \text { min after } \\
\text { reinjection }\end{array}$ & Stress & $3 \mathrm{~h}$ rest \\
\hline \multicolumn{6}{|c|}{ Defect severity score $($ mean \pm SD) } \\
\hline $17.0 \pm 8.1$ & $10.1 \pm 4.9$ & $7.1 \pm 4.5$ & $6.4 \pm 4.1$ & $3.1 \pm 4.4$ & $3.1 \pm 3.7$ \\
\hline
\end{tabular}

Table 4. Perfusion defect severity scores

\section{Three-hour resting perfusion before surgery}

The 3-h resting images revealed a significant redistribution in 19 of 21 patients with stress perfusion defects, but none of them exhibited completely normal resting images (Figure 1). The score difference between the stress and 3-h resting studies ranged from 1 to 17 , with a mean of 6.9 . 

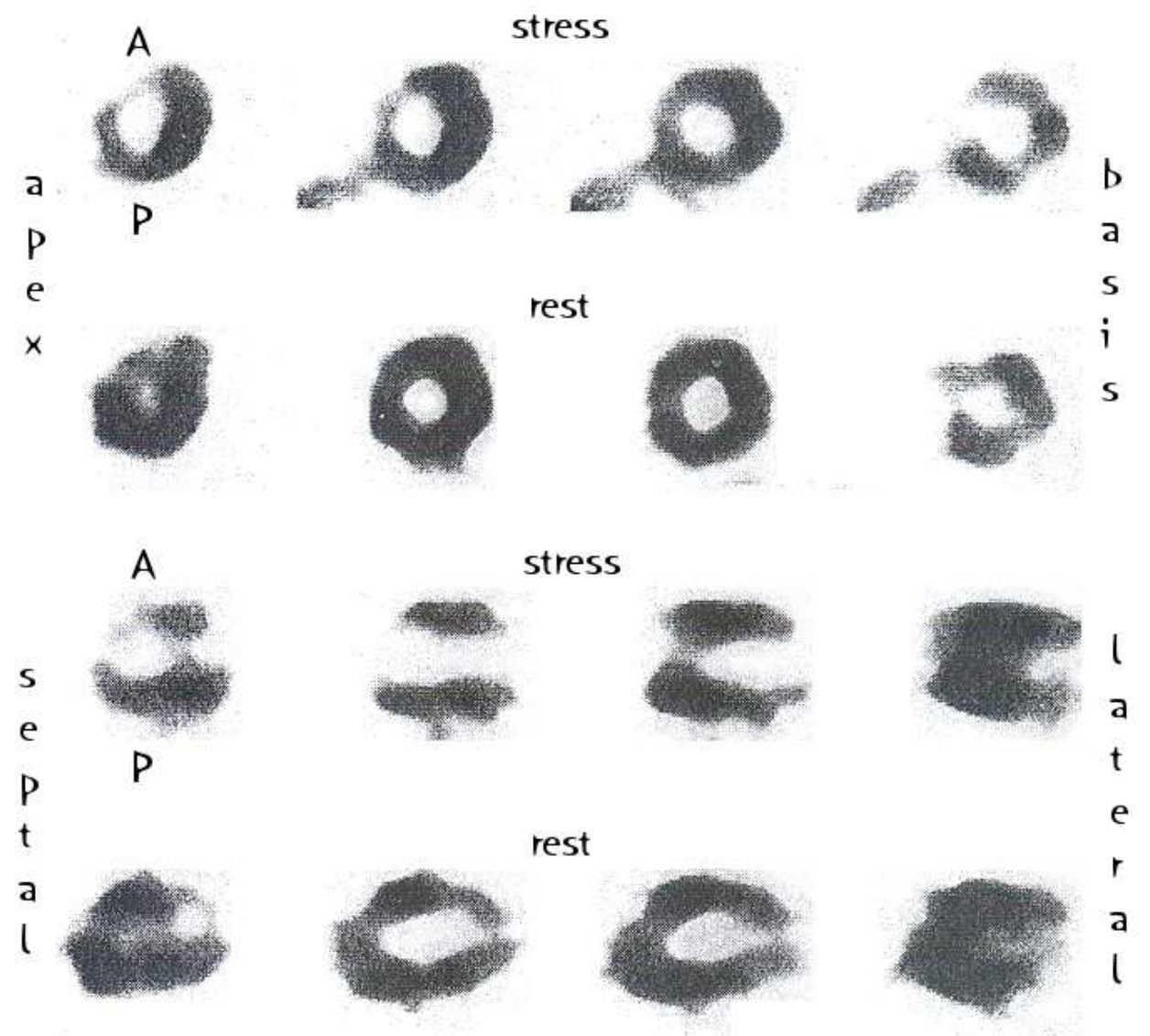

Figure 1. Dipyridamole stress myocardial perfusion scintigrams before coronary bypass surgery.

On the 3-h rest image, only partial filling of the extensive anteroseptal perfusion detect can be observed.

The two patients without significant redistribution had subtotal coronary lesions and were without anamnestic myocardial infarction. Dipyridamole infusion was completed in both patients. No medication was necessary in these cases.

The patient who had normal stress myocardial perfusion exhibited a significant paradox redistribution of the apical myocardial area on the 3-h resting image. 
Changes in ${ }^{2 O l} \mathrm{Tl}$ distribution soon after reinjection

Further decreases in defect severity and/or defect size were observed on the 10-min post-reinjection images in 14 of 22 patients with perfusion defects on the 3-h redistribution images (Figure 2). The decrease in score ranged from -3 (paradox redistribution) to 10 , with a mean of 3.0.

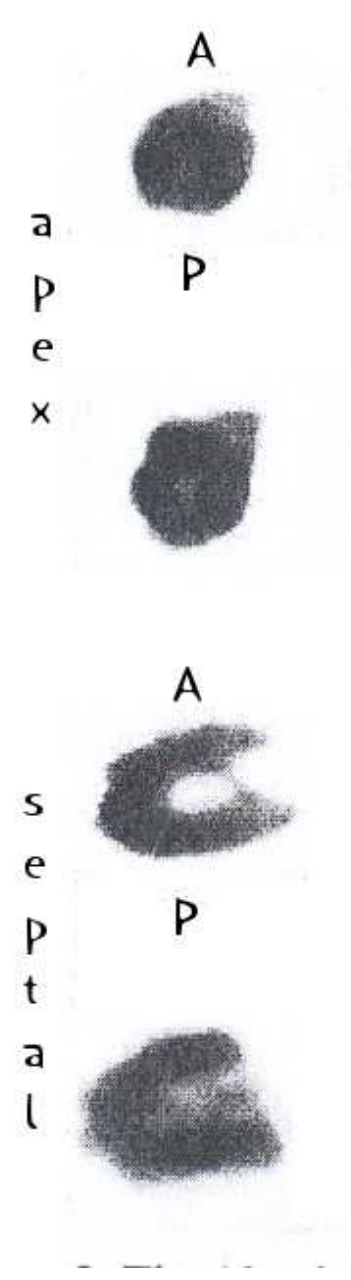

$10 \mathrm{~min}$ after reinj.
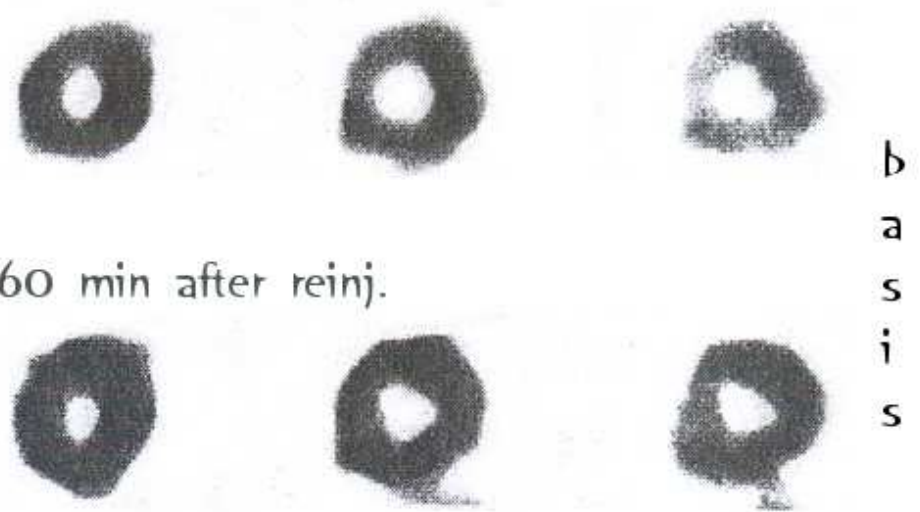

$60 \mathrm{~min}$ after reinj.
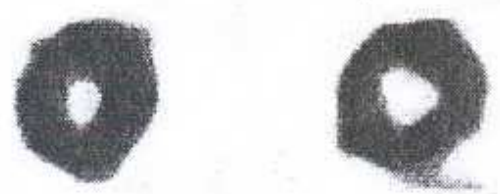

\section{(1)}

(1)

$10 \mathrm{~min}$ after reinj.
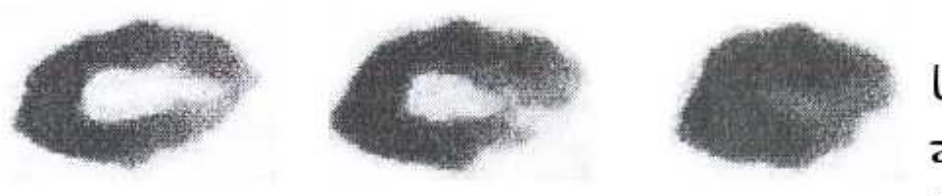

$60 \mathrm{~min}$ after reinj.
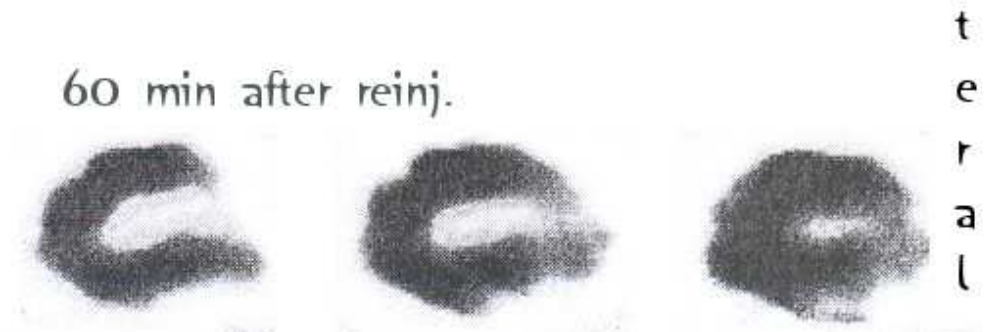

Figure 2. Dipyridamole stress myocardial perfusion scintigrams.

The 10-min post-reinjection image demonstrates further significant filling of the perfusion defects documented in Figure 1. Finally, the images taken $1 \mathrm{~h}$ after reinjection exhibit normal myocardial perfusion 
The 10-min post-reinjection images exhibited completely normal myocardial perfusion in 4 of 22 patients. The images acquired $\mathrm{t} h$ after reinjection differed significantly from the 10-min post-reinjection images in 7 of 22 patients. In four cases significant filling of perfusion defects was observed, while in three patients a paradox redistribution was noted.

\section{Perfusion after bypass surgery}

After bypass surgery, normal perfusion was found in 14 of 22 patients on both the stress and the 3-h rest images (Figure 3). A significant, but minimal redistribution was noted in four cases, and a paradox redistribution in two.

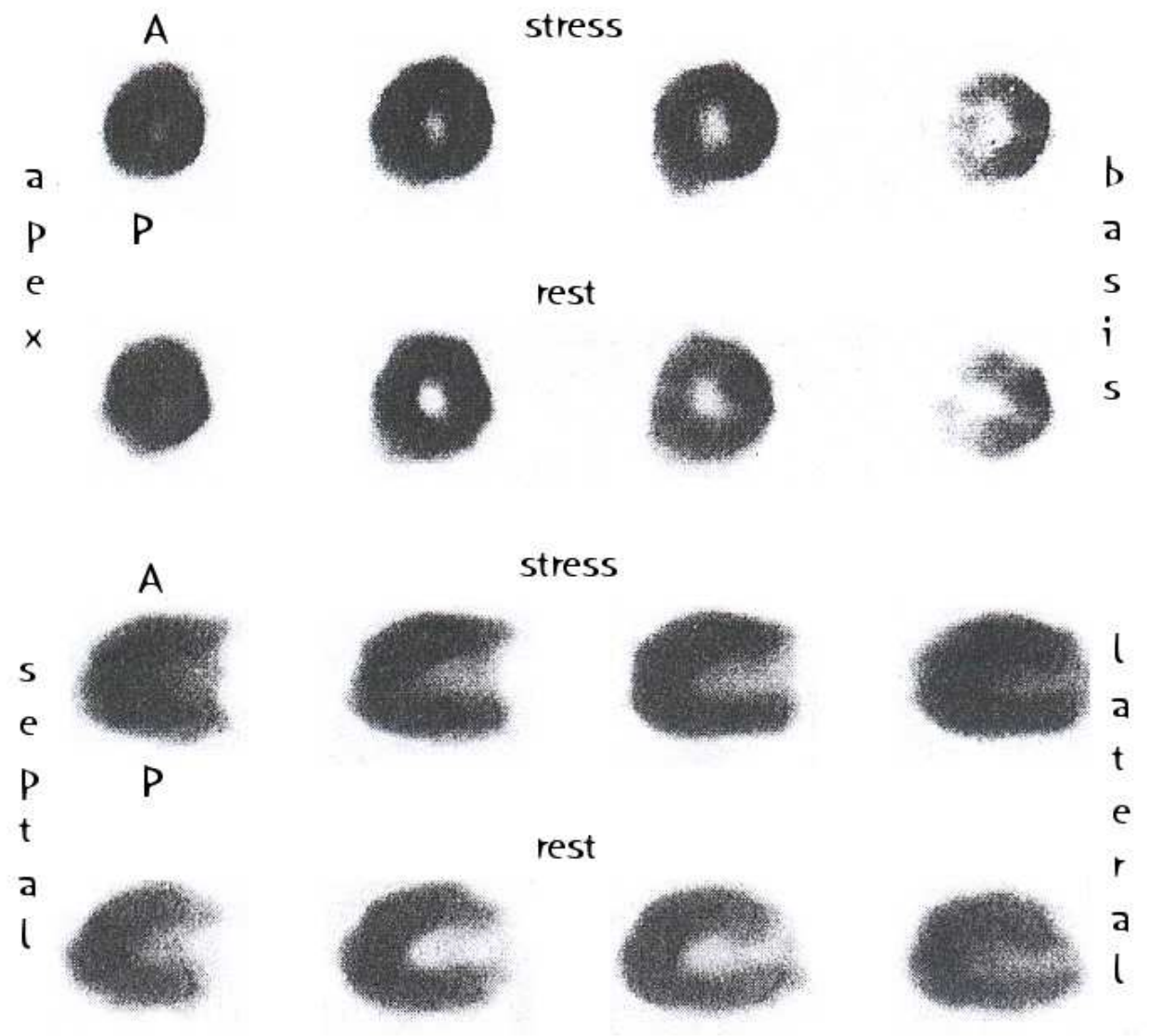

Figure 3. Dipyridamole stress myocardial perfusion scintigrams.

The stress and 3-h rest images after successful coronary bypass surgery of the same patient a sin Figure 1 and 2 document normal myocardial perfusion. 
The changes in the defect score sum are given in Table 5. A significant decrease in the mean defect score from 10.1 to 7.1 was observed after reinjection, and a further decrease from 6.4 to 3.1 after bypass surgery.

Stress images after bypass corresponded to the stress images before bypass in three cases, to the 3-h redistribution images in two cases, to the 10-min post-reinjection images in seven cases and to the 60-min post-reinjection images in 11 cases. Resting images after bypass corresponded to the stress image before bypass in three cases, to the 3 -h redistribution images in two cases, to the 10 -min post-reinjection images in seven cases and to the 60-min post-reinjection images in ten cases.

The correlation coefficients of the scores of the investigations of the patients are listed in Table 5. The 60-min post-reinjection image before surgery appears to be the best predictor of myocardial perfusion after bypass.

\begin{tabular}{|c|l|c|c|}
\hline \multicolumn{4}{|c|}{ Images before CABG } \\
\hline Stress & $3 \mathrm{~h}$ rest & $\begin{array}{c}10 \text { min after } \\
\text { reinjection }\end{array}$ & $\begin{array}{c}60 \text { min after } \\
\text { reinjection }\end{array}$ \\
\hline \multicolumn{4}{|c|}{ Stress image after CABG } \\
\hline 0.27 & 0.62 & 0.62 & 0.72 \\
\hline \multicolumn{5}{|c|}{ 3h rest image after CABG } \\
\hline 0.39 & 0.72 & 0.69 & 0.78 \\
\hline
\end{tabular}

Table 5. Correlation coefficients of perfusion defect severity scores

\section{Conclusion:}

We performed dipyridamole stress testing before and after surgery, which is a safe alternative to ergometric stress testing with similar diagnostic efficacy.

Our patient group consisted only of single-vessel LAD patients, which results in a welldefinied area at risk that can be investigated relatively free of possible imaging artefacts, e.g. due to diaphragmatic absorption. We observed a reduction in defect severity of $30 \%$ following reinjection. 
We generated two sets of reinjection images. The first was acquired, as prosposed by others, immediately after reinjection, and the second, $1 \mathrm{~h}$ later. The reason for acquisition of the second post-reinjection images was the assumption that redistribution of ${ }^{2 \mathrm{O} 1} \mathrm{Tl}$ may also occur after the second injection in patients with severe resting hypoperfusion. As regards the predictive value of preoperative scintigrams, the images obtained $1 \mathrm{~h}$ after reinjection were found to correlate most closely with postoperative study.

Our then investigations at the Szeged University of Sciences proved (52) that postreinjection ${ }^{2 \mathrm{O} 1} \mathrm{Tl}$ images before surgery are good predictors of myocardial perfusion after revascularization. The best results are obtained if imaging is performed $1 \mathrm{~h}$ after reinjection. 


\title{
II. Changes in the mortality of acute myocardial infarction in the area of Zalaegerszeg. Effects of the first 24 hour ST-elevation acute myocardial infarction intervention service in Hungary.
}

\section{Introduction:}

Invasive cardiology, i.e. primary PCI is already a basic requirement of up-to-date medical care of acute myocardial infarction nowadays $(53,54)$. However, ACC/AHA and ESC guidelines of 1999 positioned PCI as a Class I recommendation only as an alternative of thrombolysis and for the treatment of patients with a complicating cardiogenic shock $(55,56)$. First, we organized a 24 hour intervention service for acute myocardial infarction at the Department of Cardiology in the Hospital of Zala County, Zalaegerszeg, Hungary in 1998.

\begin{abstract}
Aims:
We wished to examine the effect of the Cardiology Centre at Zalaegerszeg, established in 1994, and in particular of its Haemodinamics Laboratory on mortality data of the region. The first interventions in acute myocardial infarction were performed in 1996. Our study covers the period between 1997 and 2004.
\end{abstract}

\section{Patients and Methods:}

The Western Transdanubian Regional Institute of the Hungarian National Public Health and Medical Officer Service processed the mortality data of the period between 1997 and 2005 in the Western Transdanubian Region and in the area of Zalaegerszeg, and compared those with each other and with the national average published by the Hungarian Central Statistical Office. With the help of our own computerised data base, we studied the changes in the number of invasive interventions during this period, and correlated them with mortality statistics. We studied the Hungarian national, WestTransdanubian, and Zalaegerszeg areal mortality data in relation to hypertension, stroke, malignancies and myocardial infarction. 
For studying the changes of mortality rate in time, we calculated standardised mortality rate (SMR); in order to avoid potential bias due to the small number of cases, we smoothed the data with moving averaging of 3 years' time span. For calculating the indices, we used the age distribution of "European Standard Population" of 1976 as reference (57). Analysis of mortality conditions in the area was performed on the base of mortality data in the period between 1996 and 2005. For the analysis of mortality situation, national and areal numbers of mortality of the age groups were provided for us by the National Institute of Environmental Health based on the data of the Hungarian Central Statistical Office. European data of mortality were collected from the "European Heath for All Database" of the WHO (58). We note here that our statements concerning the European Union (EU) reflect a situation before May 2004, i.e. EU of 15 member states, as our study also covers this period.

For testing the study hypothesis, we used a statistical test, the $\mathrm{Z}$ test, as $\mathrm{p}$ value determined from its result serves as a base for assessing the level of significance. No level of significance was determined for areas where the actual number of death cases was $<5$.

\section{Results:}

There were no detectable differences in mortality rates between nationwide Hungarian and regional statistics, but as compared to the average of the EU, we found approximately twofold and $1 \frac{1}{2}$ fold values in male and female patients respectively (Figure 4.). Cardiovascular diseases are responsible for approximately a half and 3/5 of mortality in men and women respectively. Analysis of mortality due to coronary disease showed no differences within the same gender but the risk of male patients was 5 times higher in comparison to female patients in the three regions studied. We found early coronary mortality in men of the Zalaegerszeg area (population between 45 and 65 years) initially higher as compared to the national and Western Transdanubian average, while there was no difference in women (Figure 5.). However, in the age group of $>65$ years a significant difference can be observed also in women (Figure 6.). During the studied period, the mortality of patients in the Zalaegerszeg area has visibly and significantly decreased both in men and in > 65 year-old women, while national and Western Transdanubian values show stagnation. Although it did not constitute a subject 
of our study, mortality rates in other areas of the Western Transdanubian region might show an increase that was compensated by the improvement in the Zalaegerszeg data.

The effect on mortality rates exerted by the Haemodinamics Laboratory can be illustrated primarily by the change in the data of early mortality due to myocardial infarction. The improvement of our mortality statistics is not due to some change in the prevalence of myocardial infarction, in 2005 such data of ours correlated with the national average (Figure 7.).

In the male population belonging to the laboratory's attraction zone, mortality rates decreased to a higher extent in both studied age groups in comparison to the national and Western Transdanubian average (Figures 7-8.). While the extent of decrease was $48 \%$ (>65-year-old population) and 51\% (45 to 64-year-old population) of the area in the last studied period in comparison to the baseline, the Hungarian national and the regional averages only approached $30 \%$. As a result of the favourable process, the $+15 \%$ relative risk of men above national average at the beginning of the period reached a mortality risk which was lower by $17 \%$ at the period's end. Also in women the decrease is marked more in the younger age group (45 to 64-year-old population: 56\%; $>65$-year-old population: $38 \%$ ), although this is less spectacular because of the relatively low mortality rate seen in the younger age group. Unfortunately, the change in the mortality rate of acute myocardial infarction was not associated with any decrease of other vascular mortality. While national and Western Transdanubian data show a decreasing trend in relation to hypertension and cerebrovascular disease, a stagnation can be seen in the Zalaegerszeg area, and even a significant increase occurred in the >65-year-old population (Figures 9-10.).

The statistical data show that, in spite of the developing diagnostic possibilities (screening programs, positron emission tomography, and gene diagnostics), the mortality caused by malignancies, responsible for approximately $1 / 4$ of the whole mortality, underwent no change during the studied decade. 


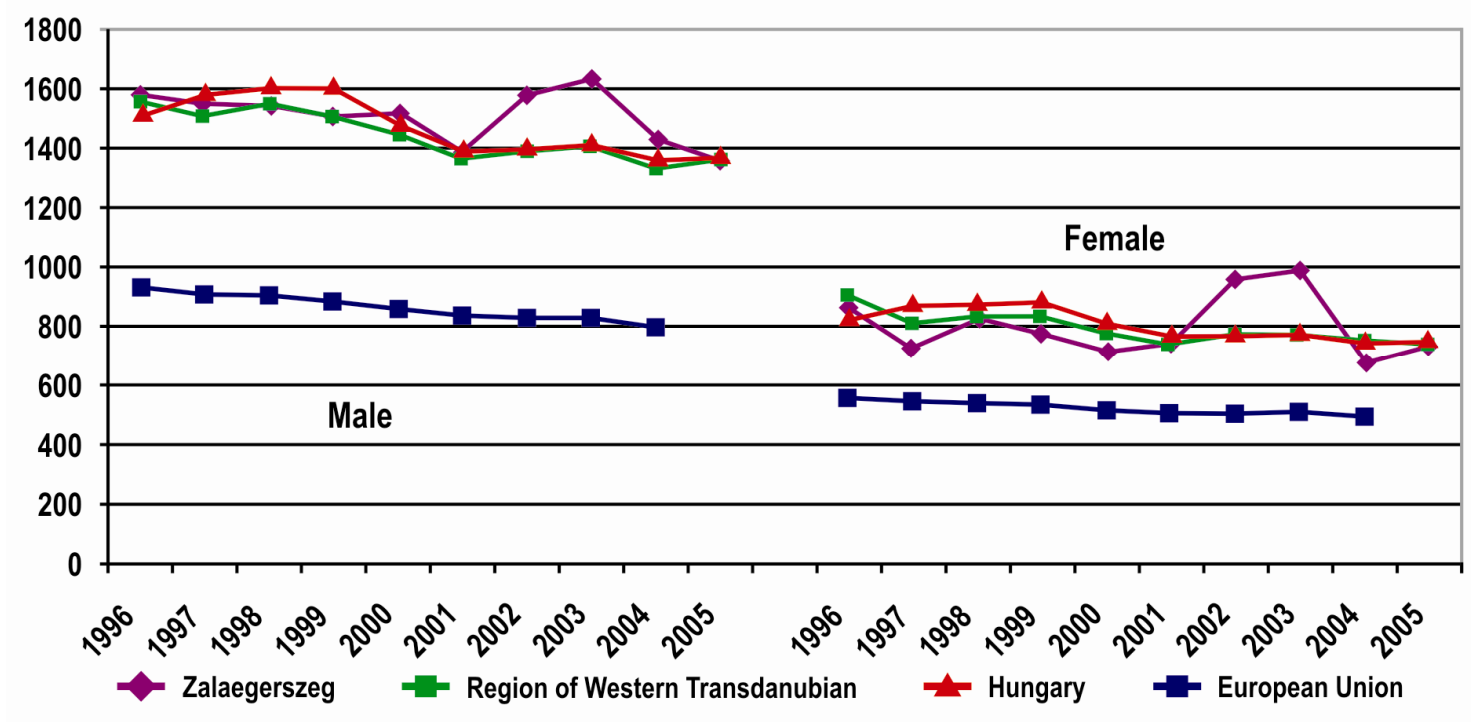

Figure 4. Changes of mortality rate according to gender among the populations of the European Union, Hungary, the Western Transdanubian region and the area of Zalaegerszeg (1996 to 2005), SMR/100 000 inhabitans

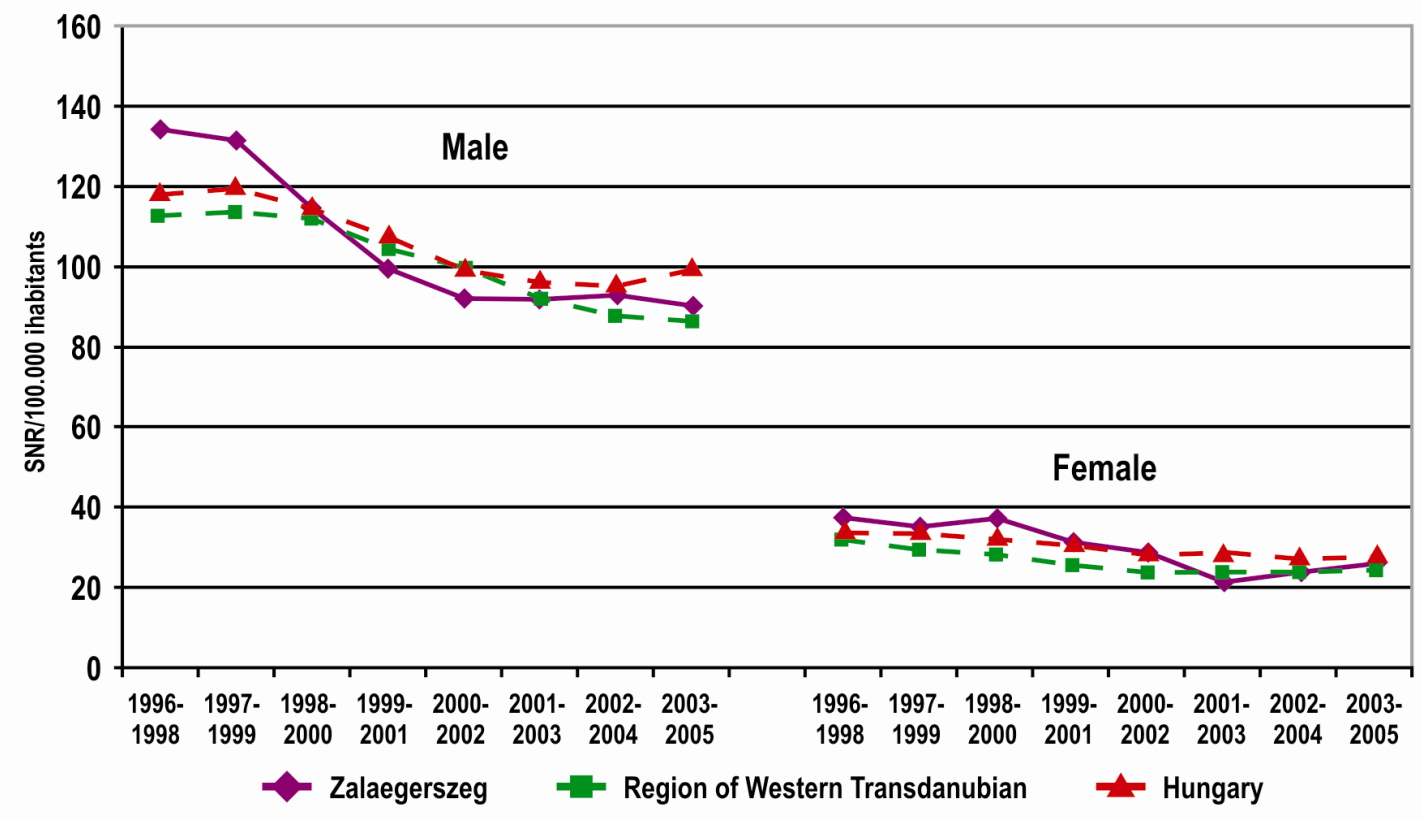

Figure 5. Early mortality due to coronary disease among men and women in Hungary, the Western Transdanubian region, and the area of Zalaegerszeg (1996 to 2005, with moving averaging of 3 years' time span) (SMR / 100000 inhabitants) 


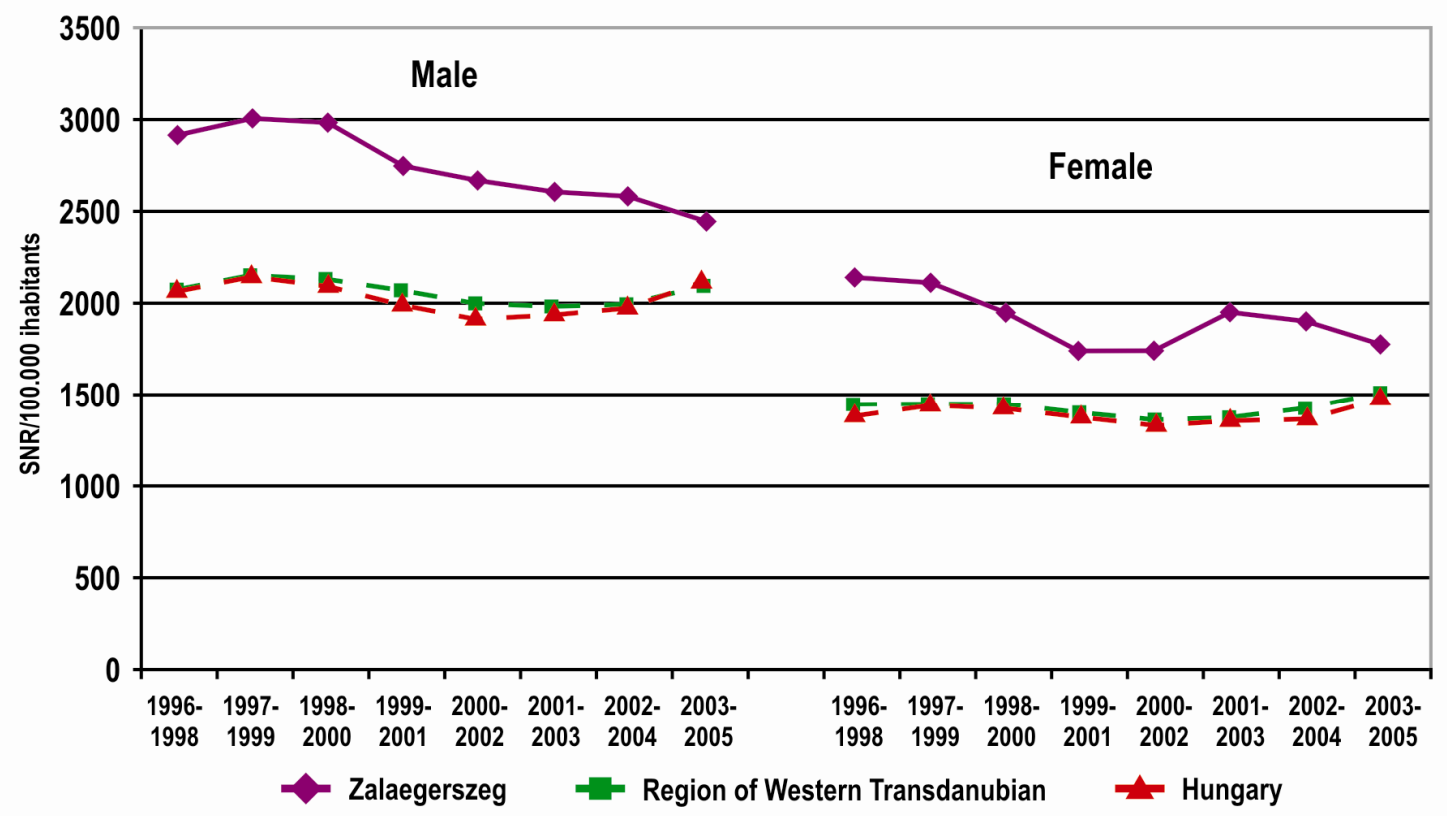

Figure 6. Mortality due to coronary disease among > 65-year-old men and women in Hungary, the Western Transdanubian region, and the area of Zalaegerszeg (1996 to 2005, with moving averaging of 3 years' time span) (SMR / 100000 inhabitans)

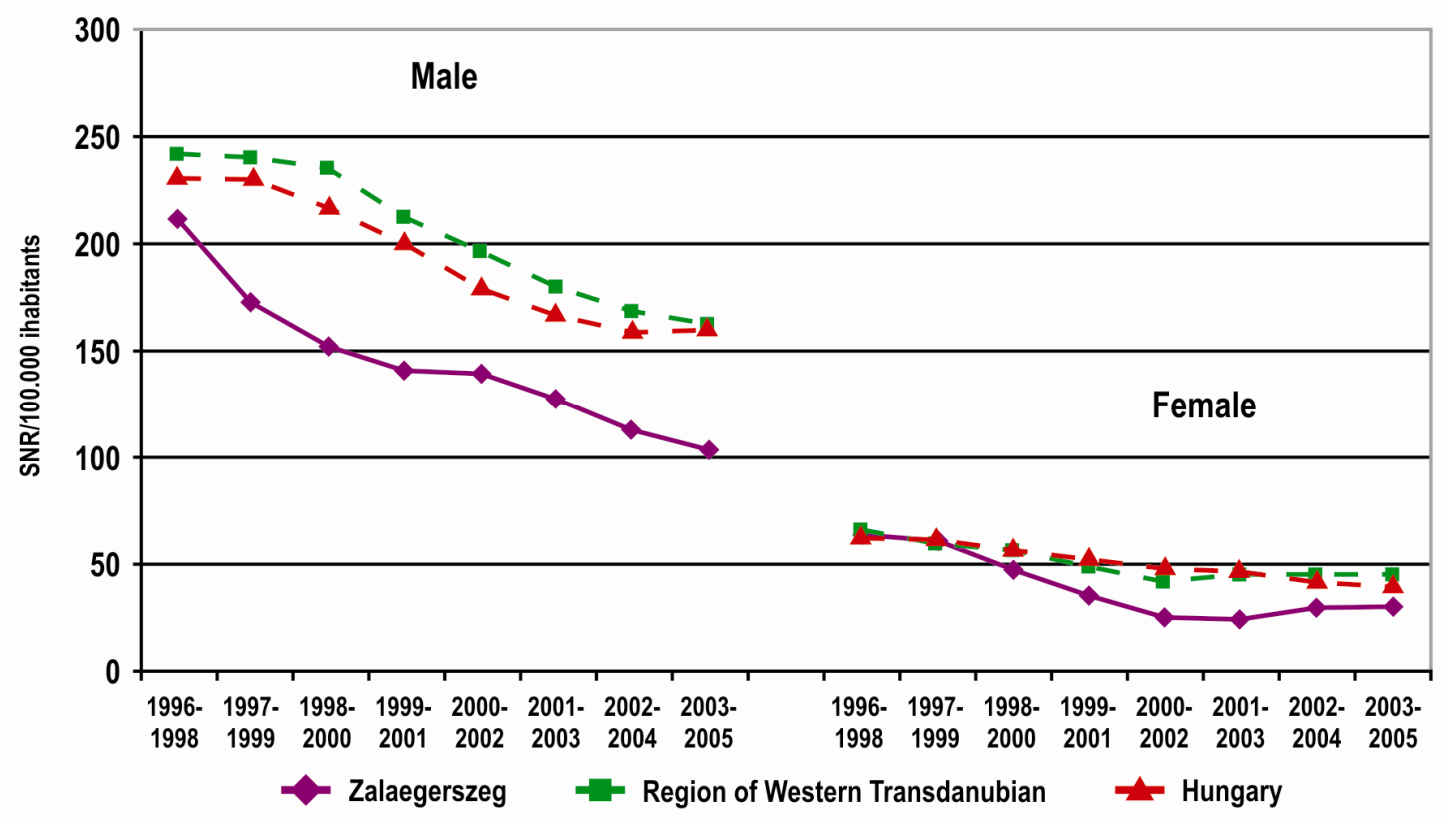

Figure 7. Mortality due to acute myocardial infarction among 45 to 65 -year-old men and women in Hungary, the Western Transdanubian region, and the area of Zalaegerszeg (1886 to 2005, with moving averaging of 3 years' time span) (SMR / 100000 inhabitants) 


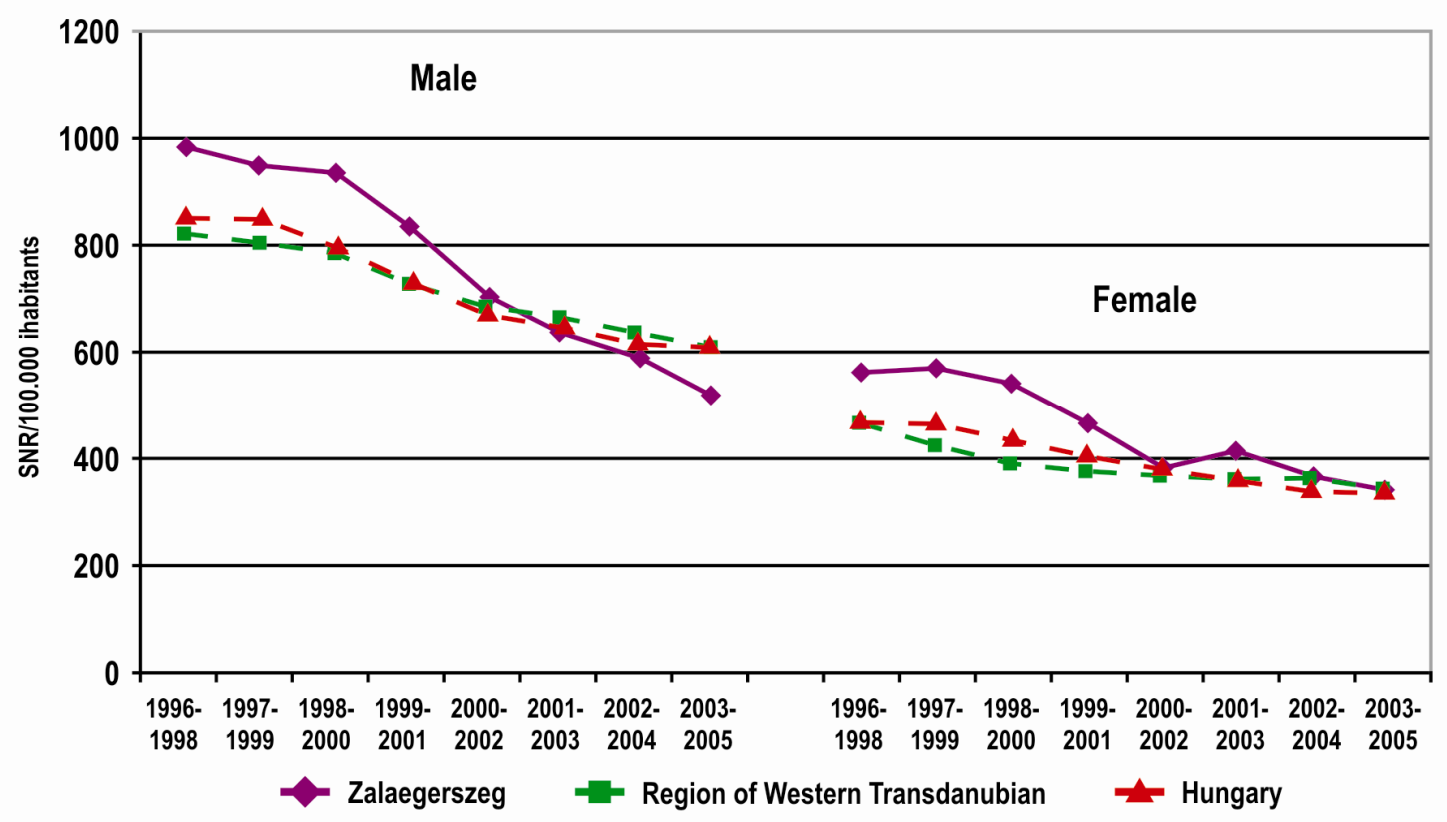

Figure 8. Mortality due to acute myocardial infarction > 65-year-old men and women in Hungary, the Western Transdanubian region, and the area of Zalaegerszeg (1996 to 2005, with moving averaging of 3 years' time span) (SMR / 100000 inhabitants)

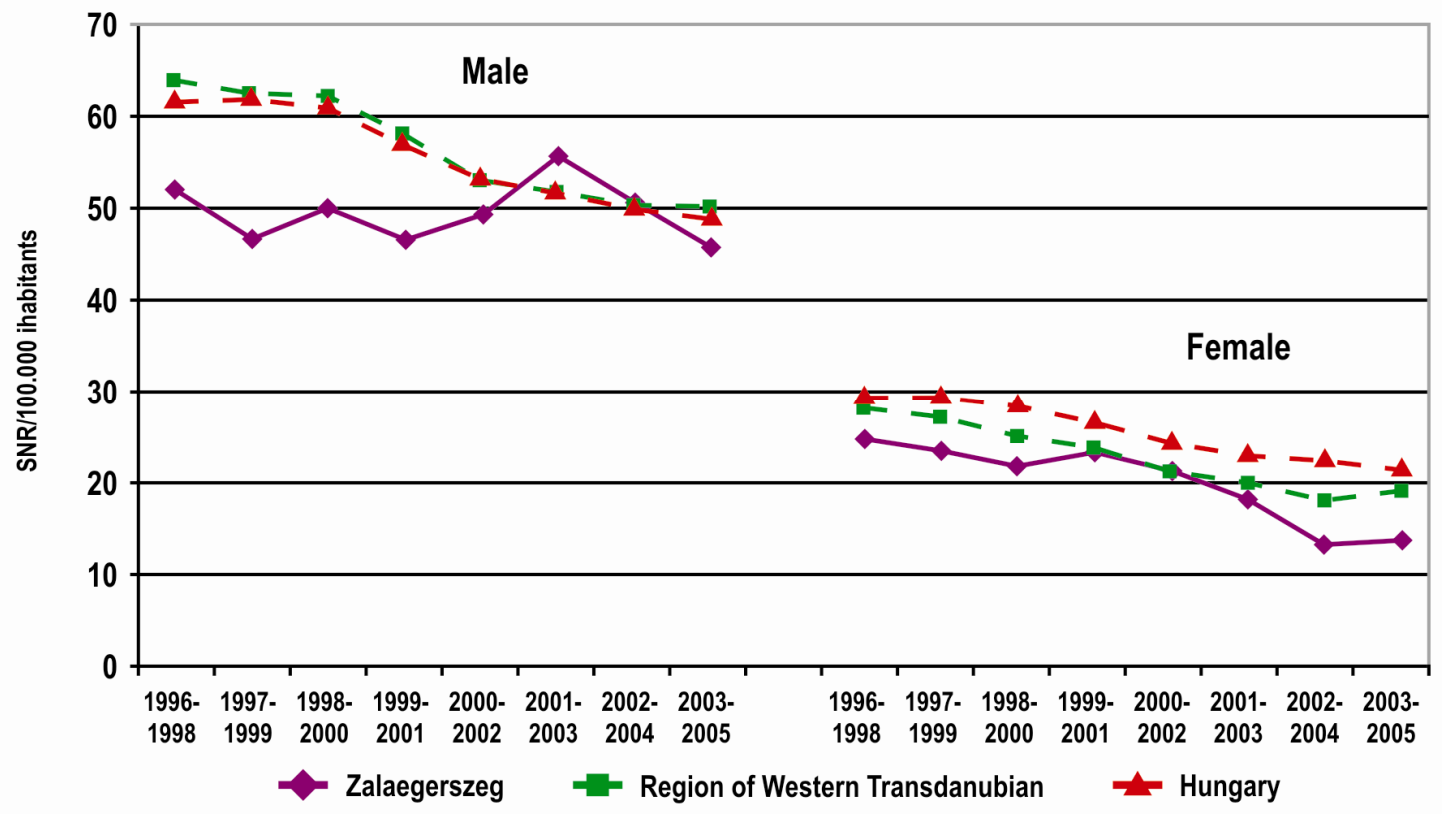

Figure 9. Early mortality due to hypertension and cerebrovascular disease among men and women in Hungary, the Western Transdanubian region, and the area of Zalaegerszeg (1996 to 2005, with moving averaging of 3 years' time span) (SMR / 100000 inhabitans) 


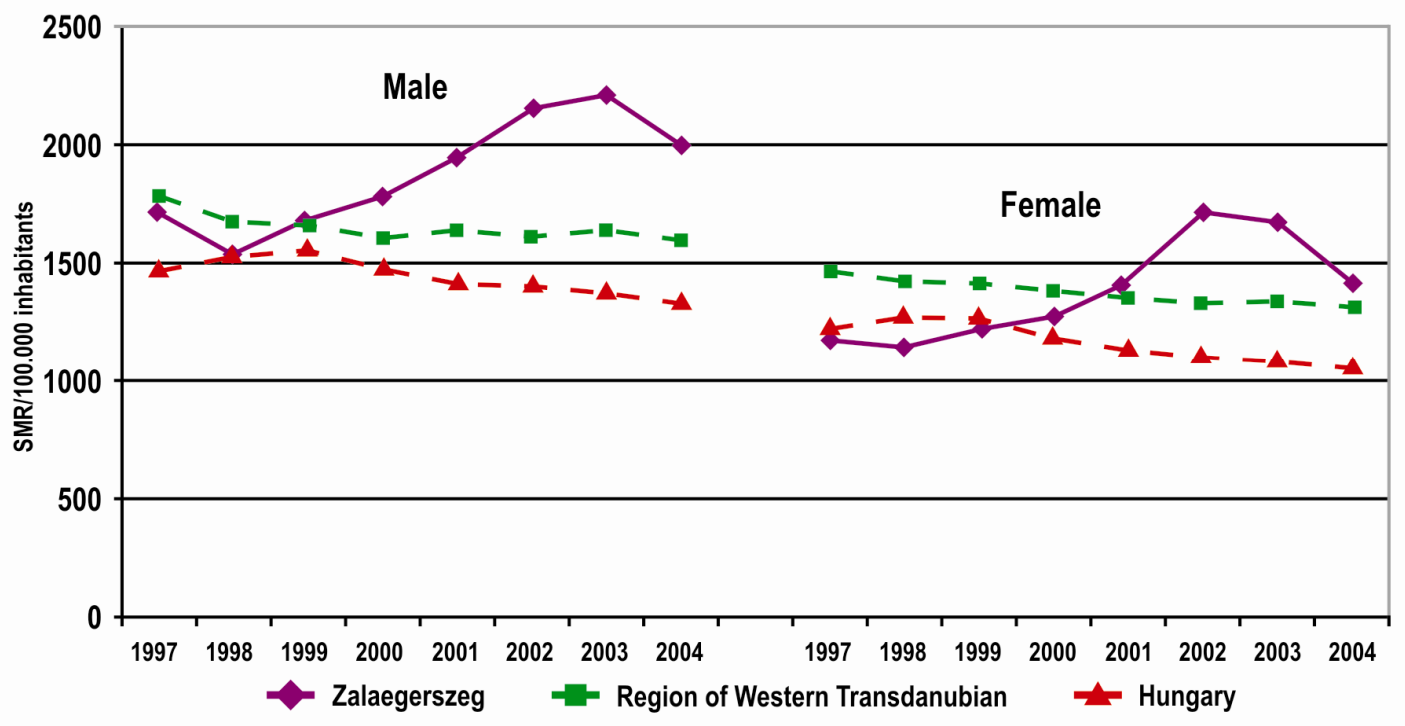

Figure 10. Early mortality due to hypertension and cerebrovascular disease among $>$ 65-year-old men and women in Hungary, the Western Transdanubian region, and the area of Zalaegerszeg

(1996 to 2005, with moving averaging of 3 years' time span) (SMR / 100000 inhabitans) 


\section{Conclusion:}

Hungarian statistics of mortality and morbidity have been led by cardiovascular diseases (59). Acute myocardial infarction constitutes the most frequent acutely developing form of cardiovascular diseases. Based on European statistics, Hungary belongs to countries with high cardiovascular risk; the mortality due to myocardial infarction significantly exceeds the average of developed countries. At the beginning of the 1990s, the cardiovascular mortality as well as the early mortality due to myocardial infarction in the Zalaegerszeg area exceeded both Western Transdanubian regional and Hungarian national averages. Based also on these dismal statistical data, the Cardiology Centre that possesses units of invasive cardiology and cardiac surgery as well was brought into being in 1994. Preceding even the European and North American recommendations, we developed a 24 hour emergency service for patients with (initially only) acute STEMI which soon extended to all kinds of acute coronary syndrome. Analyses performed yearly on the base of our own data (which demonstrated a reduction of the mortality rate in the hospital phase of STEMI) confirmed our belief that we were on the right track. Based on numerous studies published in the meantime, primary PCI for STEMI has already become a Class I/A recommendation at present $(55,56)$.

The acute 24 hour intervention care for acute myocardial infarction, launched as the first of its kind in Hungary, has improved mortality statistics of the area to a significant extent in comparison to the national average. Initially we performed primary intervention only in "selected" patients (who were young and presented themselves with a short pre-hospital interval), but at the sight of the excellent results we included an increasingly wider scope of patients into the acute care. At the beginning of the period, hospitals belonging to our region of care used lysis therapy in their patients, according to the recommendations of that time. The differences in mortality rate, particularly in 2000 to 2001, can also be considered as differences between lysis and primary PCI. It should be underlined that, although further invasive centres began functioning in the region and 16 centres provide STEMI service nationwide, the results of the experienced team which has gained great routine, represent an advantage for patients in the Zalaegerszeg area up to now. Based on our data, we can state $(60,61)$ that a significant reduction of mortality rate can be attained by primary PCI therapy of STEMI, the material and technical conditions of which have been realised, so that further development of the system at striving for perfection is justified. We have to 
seek, in addition to prevention, early recognition of the disease and - as early as possible - transport of patients, preferably directly, onto the table for catheterisation. 


\section{Experience with Endeavor stent implantations}

\section{Introduction:}

The high risk ACS (with ST segment elevation, non-ST segment elevation, troponin positive - NSTEMI) should be treated with PCI, which could be balloon angioplasty (PTCA) with or without stent implantation, or primary stent implantation. In case of PTCA re-narrowing of coronaries occurs in 30-40\% of all cases in 3-18 months after the procedure. The phenomenon is called restenosis. This is the most common disadvantage of PTCA. The incidence of restenosis can be lowered with the use of stents (the first coronary stent in a human was implanted by Sigwart et al. in 1987 (62)) to $15-30 \%$, but it can't be eliminated. The restenosist after the use of stents is called instent restenosis (ISR).

To avoid the ISR drug eluting stents (DES) were developed and used, which do not allow the neointima formation, thus ISR is very rare, indeed, but the occurrence of stent-thrombosis is higher than in cases of bare metal stents (BMS) (63).

The Endeavor is a new DES based on chrome-cobalt stent (Driver) covered in antiproliferative phosphorylcholin polymer ABT - 578 (a zotarolimus, rapamycin-like material) (64). The development of this DES was ruled by the fact that the neointima proliferation, in however small measures, is occurring, so the frequency of stentthrombosis can be reduced (65).

\footnotetext{
Aims:

In a prospective study our aim was to follow up our patients regarding to the incidence of in-stent restenosis, stent thrombosis and clinical end points (the need of new coronary angiography, revascularization) after Endeavor stent implantation. Our results have been compared to the data found in the Medline database.
}

\section{Patients and methods:}

Endeavor stents have been implanted in patients undergoing elective or acute coronary angiography in Cathlab of the Zala County Hospital with the following indications: 
Complex B and C type lesions susceptible to restenosis and after recanalization of chronic total occlusions (CTO).

Detailed database has been created in which the indication and the locus of stent implantation, the medical history and concomitant medications have been stated.

Patients were followed-up with treadmill stress test according to Bruce protocol 1, 3, 6 and 12 months after the procedure and via telephone consultations, respectively.

All patients gave their written consent.

Data were processed and statistical measurements were made using Excel software.

\section{Results:}

Endeavor DES implantations were successfully performed in 99 patients (65 male (65.6\%), 34 female (33.7\%), average age $62 \pm 12$ years) between October 2005 and September 2006. The risk factors of our patients are shown in Table 6.

\begin{tabular}{|l|c|}
\hline \multicolumn{1}{|c|}{ Risk factors } & Patients (\%) \\
\hline Diabetes mellitus & $29(29.3 \%)$ \\
\hline Hypertension & $35(35.7 \%)$ \\
\hline Myocardial infarction in medical history & $47(47.5 \%)$ \\
\hline PCI in the past & $24(24.2 \%)$ \\
\hline CABG in the past & $11(11.1 \%)$ \\
\hline Ongoing ACS & $17(17.2 \%)$ \\
\hline
\end{tabular}

Table 6. Risk factors in patients undergoing Endeavor stent implantation

The diagnostic coronary angiography proved multi coronary disease in 59 patients $(59.6 \%)$.

90 patients were treated with 1 stent, 2 stents were implanted in 6 patients, while 3 patients received 3 Endeavor stents.

Endeavor stent implantation has been successful in $98 \%$ of cases, 2 stents could not be implanted because of technical difficulties. Besides Endeavor other types of stents were 
used in 40 patients (41.4\%) (3 DES, 37 BMS). Multi vessel PTCA was performed in 20 cases, in another 20 patients Endeavor and another stent have been implanted in the same coronary artery. In the aggregate 166 stents were implanted in 99 patients (1.67 stents/patients).

The average Endeavor stent length was $23.16 \mathrm{~mm}$, the average stent diameter was 2.98 $\mathrm{mm}$.

The localization of the implanted stents was as follows:

Left anterior descending artery (LAD) 61 (25 proximally), circumflexus (CX) 11, right coronary artery (RCA) 21 (4 into the orifice), left main (LM) 3, grafts (saphena - SVG or left internal mammary artery - LIMA) 3. 29 stents were implanted in bifurcational lesions (LAD-diagonal, dominant obtuse marginal - CX-OM), recanalization of CTO with Endeavor stent has been performed in one case.

All patients were treated with the combination of $100 \mathrm{mg}$ acetylsalicylic acid (ASA) and $75 \mathrm{mg}$ clopidogrel for 12 months. The combination therapy of GP IIb/IIIa receptor blockers and intravenous Na-heparin was used in 14 patients for 12 hours following PCI.

During the follow-up period planned or unplanned coronary angiography was performed in 36 patients (36.4\%). Target vessel revascularization was necessary in 13 patients $(13,1 \%)$ (6 CABG, 7 rePTCA), 11 patients had 3 vessel disease, 9 had LADdiagonal bifurcational lesions, 1 SVG, 1 LM and 2 RCA. Five of 13 suffered from diabetes.

All stents except the ones implanted in the LM were longer than $18 \mathrm{~mm}$ (diameter ranged from 2.75 to $3.5 \mathrm{~mm}$ ).

Significant restenosis was observed in 8 patients $(8.1 \%)$.

Subacute stent-thrombosis (within 10 days) occurred in 2 patients $(2.0 \%)$. There wasn't any late stent-thrombosis.

Five patients died during the follow-up period: 2 patients due to the progression of heart failure (no restenosis), 1 patient after a huge stroke and 1 patient chilled during an alcohol abuse state. NSTEMI with cardiogenic shock due to restenosis caused the death of 1 patient. 


\section{Conclusions:}

PTCA re-narrowing of coronaries occurs in $30-40 \%$ of all cases in 3-18 months following the procedure. The incidence of restenosis can be lowered with the use of stents to $15-30 \%$. The restenosis after the use of stents is mostly due to neointima formation.

To avoid ISR, drug eluting stents are used, which block neointima formation. ISR is very rare but the incidence of stent-thrombosis exceeds those in BMSs.

The Endeavor drug eluting stent is based on a chrome-cobalt Driver stent covered in antiproliferative phosphorylcholin polymer ABT - 578. It is a rapamycin-like material, which bonds $\mathrm{FKBP}_{12}$ protein. This complex prevents the mTOR signal transmission and as a result it blocks cell cycle and tissue proliferation (66). Efficacy and safety were studied in ENDEAVOR I-III. clinical trials $(67,68,69)$. The 100 patients elected for Endeavor I trial had de novo, A-B2 type coronary stenosis, and the implanted Endeavor stents were shorter than $18 \mathrm{~mm}$. Target lesion revascularization (TLR) and target vessel failure (TVF) was $2 \%$ after 4 and 12 months and remained constant after the 24 month follow-ups. In-stent late loss was $0.61 \mathrm{~mm}$, in-stent binary restenosis was $5.4 \%$. Subacut stent-thrombosis ( $<10$ days) occurred in one patient only, and there weren't any late stent-thrombosis after the 24 month follow-ups, either. After 24 months the incidence of major acute cardiac event (MACE) was 3\% (67). These data are important in the light of several studies reporting the high incidence of late stent-thrombosis after DES implantation causing higher mortality compared to BMS in 2006 and 2007 (70, 71, 72). However these findings referred to the first generation of DESs, in case of second generation Endeavor stent these late effects could not be proven.

Our registry affirmed the results of the ENDEAVOR I. trial in a population with more severe and longer coronary stenosis. We showed that these stents are well useable (with only a $2 \%$ rate of failure), there wasn't any difference in the incidence of stentthrombosis compared to earlier results, and we could not detect late thrombosis. The prevalence of in-stent restenosis was higher compared to the ENDEAVOR I. trial, but the difference can be explained with the more complex and longer lesions in our population.

Summarizing we can conclude that the ENDEAVOR stent is suitable for implantation in complex, longer coronary lesions. Our long term follow-up data doesn't prove those 
opinions which prefer BMS implantation in all patients referring to the late adverse events of the drug eluting stents (73). 


\section{New observation}

The following conclusions can be drawn from our investigations:

1. The post-reinjection ${ }^{201} \mathrm{Tl}$ images before surgery are good predictors of myocardial perfusion after revascularization. The best results are obtained if imaging is performed 1 hour after reinjection.

2. Introduced the first 24-hour duty in Hungary to provide primery PCI care for STEMI patients.

3. The acute 24 hour intervention care for acute myocardial infarction has improved mortality statistics of the area to a significant extent in comparison to national and regional average.

4. The extension of STEMI invasive care to the elderly shows good results similar to those in younger age groups.

5. We have created an Endeavor registry involving "real world" patients.

6. Our Endeavor-registry affirmed the results of the ENDEAVOR I. trial in a population with more severe and longer coronary stenosis.

7. The professional team, which I am the head of, first proved that the ENDEAVOR stent is suitable for implantation in complex, longer coronary lesions.

8. Our long term follow-up data don't prove those opinions which prefer bare metal stent implantation in all patients because of the late adverse events of the drug eluting stents. 


\section{Acknowledgments}

These studies were carried out at the University of Szeged Faculty of Medicine and Zala County Hospital, Department of Cardiology, Zalaegerszeg.

I am grateful for the help of my project leader, Professor Tamás Forster, who managed my studies and provided support and useful advice throughout my work.

I also express my thanks to my teachers Professor Miklós Csanády, Professor László Csernay, Professor Gábor Kovács, Tibor Gaál MD., and my collegue Professor János Mester.

I am also thankful to my collegues Ákos Motyovszki MD., Zoltán Németh MD., István Takács MD., András Kenéz MD., Barnabás Németh MD. and Elöd Papp MD. for assisting in the clinical aspects of the studies and thanks to all staff members of the Cathlab, Zala County Hospital for their assistance during procedures and data collection.

I express my gratitude and thanks to my Parents and my wife, Tünde Tóth MD. for their encouraging support during all my studies and research work. 


\section{References}

1. Thygesen K, Alpert JS, White HD. Universal definition of myocardial infarction. Eur Heart J 2007; 28: 2525-2538.

2. Fuster V, Moreno PR, Fayad ZA, Corti R, Badimon JJ. Atherothrombosis and highrisk plaque: part I: evolging concepts. J Am Coll Cardiol 2005; 46: 937-954.

3. Rodriguez-Granillo GA, Garcia-Garcia HM, Valgimigli M, Vaina S, van Mieghem C, van Geuns RJ, van der Ent M, Regar E, de Jaegere P, van der Giessen W, de Feyter P, Serruys PW. Global characterization of coronary plaque rupture phenotype using three-vessel intravascular ultrasound radiofrequency data analysis. Eur Heart J 2006; 27: 1921-1927.

4. Detrano R, Guerci AD, Carr JJ, Bild DE, Burke G, Folsom AR, Liu K, Shea S, Szklo M, Bluemke DA, O'Leary DH, Tracy R, Watson K, Wong ND, Kronmal RA. Coronary calcium as a predictor of coronary events in four racial or ethnic groups. N Engl J Med 2008; 358: 1336-1345.

5. Rittersma SZ, van der Wal AC, Koch KT, Piek JJ, Henriques JP, Mulder KJ, Ploegmakers JP, Meesterman M, de Winter RJ. Plaque instability frequently occurs days or weeks before occlusive coronary thrombosis: a patholigical thrombectomy study in primary percutaneous coronary intervention. Circulation 2005; 111: 11601165.

6. Hansson GK. Inflammation, atherosclerosis and coronary artery disease. $N$ Engl $J$ Med 2005; 352: 1685-1695.

7. Libby P, Theroux P. Pathophysiology of coronary artery disease. Circulation 2005; 111: $3481-3488$

8. Lee KW, Lip GY, Tayebjee M, Foster W, Blann AD. Circulating endothelial cells, von Willebrand factor, interleukin-6, and prognosis in patients with acute coronary syndromes. Blood 2005; 105: 526-532.

9. Stone PH. Triggering myocardial infarction. N Engl J Med 2004; 351: 1716-1718.

10. Davies MJ. The pathophysiology of acute coronary syndromes. Heart 2000; 83: 361-366.

11. Keeley EC, Boura JA, Grines CL. Comparison of primary and facilitated percutaneous coronary interventions for ST-elevation myocardial infarction: 
quantitative review of randomised trials. Lancet 2006; 367: 579-588.

12. Tunstall-Pedoe H, Kuulasmaa K, Mähönen M, Tolonen H, Ruokokoski E, Amouyel P. Contribution of trends in survival and coronary-event rates to changes in coronary heart disease mortaility: 10-year results from 37 WHO MONICA projekt populations. Monitoring trends and determinants in cardiovascular disease. Lancet 1999; 353: 1547-1557.

13. Goldberj RJ, Glatfelter K, Burbank-Schmidt E, Lessard D, Gore JM. Trends in community mortality due to coronary heart disease. Am Heart J 2006; 151: 501507.

14. Armstrong PW, Granger CB, Adams PX, Hamm C, Holmes D Jr. O'Neil WW, Todaro TG, Vahanian A, Van de Werf F. Pexelizumab for acute ST-elevation myocardial infarction in patients undergoing primary peructaneous coronary intervention: a randomized controlled trial. JAMA 2007; 297: 43-51.

15. Primary versus tenecteplase-facilitated percutaneous coronary intervention in patients with ST-segment elevation acute myocardial infarction (ASSENT-4 PCI): randomised trial. Lancet 2006; 367: 569-578.

16. Le May MR, So DY, Dionne R, Glover CA, Froeschl MP, Wells GA, Davies RF, Sherrard HL, Maloney J, Marquis JF, O'Brien ER, Trickett J, Poirier P, Ryan SC, Ha A, Joseph PG, Labinaz M. A citywide protocol for primary PCI in ST-segment elevation mycoardial infarction. N Engl J Med 2008; 358: 231-240.

17. Bassand JP, Danchin N, Filippatos G, Gitt A, Hamm C, Silber S, Tubaro M, Weidinger F. Implementation of reperfusion therapy in acute myocardial infarction. A policy statement from the European Society of Cardiology. Eur Heart J 2005; 26: 2733-2741.

18. Lee KL, Woodlief LH, Topol EJ, Weaver WD, Betriu A, Col J, Simoons M, Aylward P, Van de Werf F, Califf RM. Predictors of 30-day mortality in the era of reperfusion for acute myocardial infarction. Results from an international trial of 41.021 patiens. GUSTO-I Investigators. Circulation 1995; 91: 1659-1668.

19. Fox KA, Dabbous OH, Goldberg RJ, Pieper KS, Eagle KA, Van de Werf F, Avezum A, Goodman SG, Flather MD, Anderson FA Jr, Granger CB. Prediction of risk of death and myocardial infarction in the six months after presentation with acute coronary syndrome: prosptective multinational observational study (GRACE). BMJ 2006; 333: 1091-1094. 
20. Morrow DA, Antman EM, Charlesworth A, Cairns R, Murphy SA, de Lemos JA, Giugliano RP, McCabe $\mathrm{CH}$, Braunwald E. TIMI risk score for ST-elevation myocardial infarction: a conventient, bedside, clinical score for risk assessment at presentation: an intravenous nPA for treatment of infarcting mycoardium early II trial substudy. Circulation 2000; 102: 2031-2037.

21. Schomig A, Mehilli J, Antoniucci D, Ndrepepa G, Markwardt C, Di Pede F, Nekolla SG, Schlotterbeck K, Schühlen H, Pache J, Seyfarth M, Martinoff S, Benzer W, Schmitt C, Dirschinger J, Schwaiger M, Kastrati A; Beyond $12 \mathrm{~h}$ Reperfusion AlternatiVe Evaluation (BRAVE-2) Trial Investigators. Mechanical reperfusion in patients with acute myocardial infarction presenting more than 12 hours from symptom onset: a randomized controlled trial. JAMA 2005; 293: 2865 2872 .

22. Hochman JS, Lames GA, Buller CE, Dzavik V, Reynolds HR, Abramsky SJ, Forman S, Ruzyllo W, MaggIoni AP, White H, Sadowski Z, Carvalho AC, Rankin JM, Renkin JP, Steg PG, Mascette AM, Sopko G, Phisterer ME, Leor J, Fridrich V, Mark DB, Knatterud GL. Coronary intervention for persistent occlusion after myOcardial infarction. N Engl J Med 2006; 355: 2395-2407.

23. Menon V, Pearte CA, Buller CE, Steg PG, Forman SA, White HD, Marino P, Katritis DG, Caramori P, Lasevitch R, Loboz-Grudzien K, Zurakowki A, Lamas GA, Hochman JS. Lack of benefit from percutaneous intervention of persistently occluded infarct arteries after the acute phase of mycoardial infarction is time independent: insights from Occluded Artery Trial. Eur Heart J 2009; 30: 183-191.

24. Canto JG, Every NR, Magid DJ, Rogers WJ, Malmgren JA, Frederick PD, French WJ, Tiefenbrunn AJ, Misra VK, Kiefe Cl, Barrnon HV. The volume of primary angioplasty procedures and survival after acute myocardial infarction. National Registry of Myocardial Infarction 2 Intvestigators. N Engl J Med 2000; 342: $1573-$ 1580 .

25. Spaulding C, Morice MC, Lancelin B, El Haddad S, Lepage E, Bataille S, Tresca JP, Mouranche X, Fosse S, Monchi M, de Venrejoul N. Is the volume-outcome relation still an issue in the era of PCI with systematic stenting? Results of the greater Paris area PCI registry. Eur Heart J 2006; 27: 1054-1060.

26. Keeley EC, Boura JA, Gines CL. Primary angioplasty versus intravenous thrombolytic therapy for acute mycoardial infarction: a quantitative review of 23 randomised trials. Lancet 2003; 361: 13-20. 
27. Grines CL, Cox DA, Stone GW, Garcia E, Mattos LA, Giambartolomei A, Brodie BR, Madonna O, Eijgelshoven M, Lansky AJ, O'Neil WW, Morice MC. Coronary angioplasty with or without stent implantation for acute myocardial infarction. Stent Primary Angioplasty in Myocardial Infarction Study Group. N Engl J Med 1999; 341: 1949-1956.

28. Stone GW, Grines CL, Cox DA, Garcia E, Tcheng JE, Griffin JJ, Guagliumi G, Stuckey T, Turco M, Carroll JD, Rutherford BD, Lansky AJ. Comparison of angioplasty with stenting, with or without abciximab, in acute myocardial infarction. N Engl J Med 2002; 346: 957-966.

29. Spaulding C, Henry P, Teiger E, Beatt K, Bramucci E, Carrie D, Slama MS, Merkely B, Erglis A, Margheri M, Varenne O, Cebrian A, Stoll HP, Snead DB, Bode C. Sirolimus-eluting versus uncoated stents in acute myocardial infarction. $N$ Engl J Med 2006; 355: 1093-1104.

30. Laarman GJ, Suttorp MJ, Dirksen MT, van Heerebeek L, Kiemeneij F, Slagboom T, van der Wieken LR, Tijssen JG, Rensing BJ, Patterson M. Paclitaxel-eluting versus uncoated stents in primary percutaneous coronary intervention. N Engl J Med 2006; 355: $1105-1113$.

31. Kastrati A, Dibra A, Spaulding C, Laarman GJ, Menichelli M, Valgimigli M, Di Lorenzo E, Kaiser C, Tierala I, Mehili J, Seyfarth M, Varenne O, Dirksen MT, Percoco G, Varricchio A, Pittl U, Syvanne M, Suttorp MJ, Vilolini R, Schomig A. Meta-analysis of randomized trials on drug-eluting stents vs. Bare-metal stents in patients with acute mycoardial infarction. Eur Heart J 2007; 28: 2706-2713.

32. De Luca G, Suryapranate H, Zijlstra F, van 't Hof AW, Hoorntje JC, Gosselink AT, Dambrink JH, de Boer MJ. Symptom-onset-to-balloon time and mortality in patients with acute mycoardial infarction treated by primary angioplasty. J Am Coll Cardiol 2003; 42: 991-997.

33. Nallamothu B, Fox KA, Kennely BM, Van de Werf F, Gore JM, Steg PG, Granger CB, Dabbous OH, Kline-Rogers E, Eagle KA. Relationship of treatment delays and motality in patienst undergoing fibrinolysis and primary percutaneous coronary intervention. The Global Registry of Acute Coronary Events. Heart 2007; 93: 15521555.

34. Nallamothu BK, Bates ER. Percutaneous coronary intervention versus fibrinolytic therapy in acute myocardial infarction: is timing (almost) everything? Am J Cardiol 2003; 92: 824-826. 
35. Betriu A, Masotti M. Comparison of mortality rates in acute myocardial inarction treated by percutaneous coronary intervention versus fibrinolysis. Am J Cardiol 2005; 95: 100-101.

36. Nallamothu BK, Antman EM, Bates ER. Primary percutaneous coronary intervention versus fibrinolytic therapy in acute mycoardial infarction: does the choice of fibrinolytic agent impact on the importance of time-to-treatment? Am J Cardiol 2004; 94: 772-774.

37. Boersma E. Does time matter? A pooled analysis of randomized clinical trials comparing primary percutaneous coronary intervention and in-hospital fibrinolysis in acute mycoardial infarction patients. Eur Heart J 2006; 27: 779-788.

38. Pinto DS, Kirtane AJ, Nallamothu BK, Murphy SA, Cohen DJ, Laham RJ, Cutlip DE, Bates ER, Frederick PD, Miller DP, Carrozza JP Jr, Antman EM, Cannon CP, Gibson CM. Hospital delays in reperfusion for ST-elevation myocardial infarction: implication when selecting a reperfusion strategy. Circulation 2006; 114: 20192025.

39. Kastrati A, Mehili J, Nekolla S, Bollwein H, Martinoff S, Pache J, Schuhlen H, Seyfarth M, Gawaz M, Neumann FJ, Dirschinger J, Schwaiger M, Schomig A. A randomized trial comparing mycoardial salvage achieved by coronary stenting versus balloon angioplasty in patients with acute mycoardial infarction considered ineligible for reperfusion therapy. J Am Coll Cardiol 2004; 43: 734-741.

40. Hochman JS, Sleeper LA, Webb JG, Sanborn TA, White HD, Talley JD, Buller CE, Jacobs AK, Slater JN, McKinlay SM, Lejemtel TH. Early revascularization in acute myocardial infarction complicated by cardiogenic shock. SHOCK Investigators. Should we emergently revascularize occluded coronaries for cardiogenic shock. $N$ Engl J Med 1999; 341: 625-634.

41. Ellis SG, Tendera M, de Belder MA, van Boven AJ, Widimsky P, Janssens L, Andersen HR, Betriu A, Savonitto S, Adamus J, Peruga JZ, Kosmider M, Katz O, Neunteufl T, Jorgova J, Dorobantu M, Grinfeld L, Armstrong P, Brodie BR, Hermann HC, Montalescot G, Neumann FJ, Effron MB, Barnathan ES, Topol EJ; FINESSE Investigators. Facilitated PCI in patients with ST elevation mycoardial infarction. N Engl J Med 2008; 358: 2205-2217.

42. Van't Hof AW, Ten Berg J, Heestermans T, Dill T, Funck RC, van Werkum W, Dambrink JH, Suryapranata H, van Houwlingen G, Ottervanger JP, Stella P, Giannitsis E, Hamm C; Ongoing Tirofiban In Myocardial infarction Evaluation 
(On-Time) 2 study group. Prehospital initiation of tirofiban in patients with ST elevation mycoardial infarction undergoing primary angioplasty (On-TIME 2): a multicentre, double-bling, randomised controlled trial. Lancet 2008; 372: 537-546.

43. Gershlick AH, Stephens-Llyod A, Hughes S, Abrams KR, Stevens SE, Uren NG, de Belder A, Davis J, Pitt M, Banning A, Baumbach A, Shiu MF, Schofield P, Dawkins KD, Henderson RA, Oldroyd KG, Wilcox R. Rescue angioplasty after failed thrombolytic therapy for acute myocardial infarction. N Engl J Med 2005; 353: $2758-2768$.

44. Wijeysundera HC, Vijayaraghavan R, Nallamothu BK, Foody JM, Krumpholz HM, Philips CO, Kashani A, You JJ, Tu JV, Ko DT. Rescue angiooplasty or repeat fibrinolysis after failed fibrinolytic therapy for ST-segment myocardial infarction: a meta-analysis of randomized trials. J Am Coll Cardiol 2007; 49: 422-430.

45. Thielmann M, Massoudy P, Neuhauser M, Tsagakis K, Marggraf G, Kamler M, Mann K, Erbel R, Jakob H. Prognostic value of preoperative cardiac troponin I in patients undergoing emergency coronary artery bypass surgery with non-STelevation or ST-elevation acute coronary syndromes. Circulation 2006; 114 (Suppl 1):1448-1453.

46. Lee DC, Oz MC, Weinberg AD, Ting W. Appropriate timing of surgical intervention after transmural acute mycoardial infarction. J Thorac Cardiovasc Surg 2003; 125: 115-119.

47. Schinkel AF, Bax JJ, Poldermans D, Elhendy A, Ferrary R, Rahimtoola SH. Hibernating mycoardium: diagnosis ant patient outcomes. Curr Probl Cardiol 2007; 32: $375-410$.

48. Dilsizian V, Rocco TP, Freedman NM, Leon MB, Bonow RO. Enhanced detection of ischemic but viable myocardium by the reinjection of thallium after stressredistribution imaging. $N$ Eng $J$ Med 1990; 323: 141-146.

49. Tamaki N, Ohtani H, Yonekura Y, Nohara R, Kambara H, Kawai C, Hirata K, Ban T, Konishi J. Significance of fill-in after thallium-201 reinjection following delayed imaging: comparison with regional wall motion and angiographic findings. $\mathrm{J} \mathrm{Nucl}$ Med 1990; 31: 1617-1623.

50. Cuocolo A, Pace L., Ricciardelli B., Chiraiello M., Trimarco B., Salvatore M.: Identification of viable myocardium in patients with chronic coronary artery disease: comparison of thallium-201 scintigraphy with reinjection and technetium99m-methoxyisobutyl isonitrile. J Nucl Med 1992; 33: 505-511. 
51. Ohtani H, Tamaki N, Yonekura Y, Mohiuddin IH, Hirata K, Ban T, Konishi J. Value of thallium-201 reinjection after delayed SPECT imaging for predicting reversible ischemia after coronary artery bypass grafting. Am J Cardiol 1990; 66: 394-399.

52. Mester J, Kósa I, Lupkovics G, Gruber N, Lázár M, Kovács G, Csernay L. Prospective evaluation of thallium-201 reinjection in single-vessel coronary patients undergoing coronary bypass surgery. Eur J Nucl Med 1993; 20: 213-218.

53. Julian DG, Boissel JP, De Bono DP. Acute myocardial infarction: pre-hospital and in-hospital management. The Task Force on the Management of Acute Myocardial Infarction of the European Society of Cardiology. Eur Heart J, 1996, 17: 43-63.

54. Van der Werf F, Ardissino D, Betriu A, Cokkinos DV, Falk E, Fox KA, Julian D, Lengyel M, Neumann FJ, Ruzyllo W, Thygesen C, Underwood SR, Vahanian A, Verheugt FW, Wijns W. Management of acute myocardial infarction in patients presenting with ST segment elevation. The Task Force on the Management of Acute Myocardial Infarction of the European Society of Cardiology. Eur Heart J 2003, 24: $28-66$.

55. Antman EM, Hand M, Armstrong PW, Bates ER, Green LA, Halasyamani LK, Hochman JS, Krumholz HM, Lamas GA, Mullany CJ, Pearle DL, Sloan MA, Smith SC Jr; 2004 Writing Committee Members, Anbe DT, Kushner FG, Ornato JP, Jacobs AK, Adams CD, Anderson JL, Buller CE, Creager MA, Ettinger SM, Halperin JL, Hunt SA, Lytle BW, Nishimura R, Page RL, Riegel B, Tarkington LG, Yancy CW. 2007 Focused update of the ACC/AHA 2004 Guidelines for the Management of Patients With ST-Elevation Myocardial Infarction. A report of the American College of Cardiology/American Heart Association Task Force on Practice Guidelines. Circulation 2008, 117: 296-329.

56. Van de Werf F, Bax J, Betriu A, Blomstrom-Lundqvist C, Crea F, Falk V, Filippatos G, Fox K, Huber K, Kastrati A, Rosengren A, Steg PG, Tubaro M, Verheugt F, Weidinger F, Weis M; ESC Committee for Practice Guidelines (CPG), Vahanian A, Camm J, De Caterina R, Dean V, Dickstein K, Filippatos G, FunckBrentano C, Hellemans I, Kristensen SD, McGregor K, Sechtem U, Silber S, Tendera M, Widimsky P, Zamorano JL, Silber S, Aguirre FV, Al-Attar N, Alegria E, Andreotti F, Benzer W, Breithardt O, Danchin N, Di Mario C, Dudek D, Gulba D, Halvorsen S, Kaufmann P, Kornowski R, Lip GY, Rutten F. Management of acute myocardial infarction in patients presenting with persistent ST-segment 
elevation: the Task Force on the Management of ST-Segment Elevation Acute Myocardial Infarction of the European Society of Cardiology. Eur Heart J 2008, 29: 2909-2945.

57. European Health for All Database, WHO/Europe, 2007. www.euro.who.int

58. Epidemiology Dictionary. In: V. Hajdú P., Ádány R. (Eds.) Medicina Publisher Ltd., Budapest, 2003.

59. Health Statistical Annual (Hungary) 1996-2006. Central Statistical Office, Budapest, 1997-2008.

60. Lupkovics G, Motyovszki Á, Németh Z, Takács I, Kenéz A, Burkali B, Menyhárt I. Mortality rate of acute heart attack in Zalaegerszeg micro-region. Results of the first Hungarian 24 hour acute myocardial infarction intervention care unit. Orv Hetil 2010, 151(14): 565-571.

61. Lupkovics G, Motyovszki Á, Németh Z, Takács I, Kenéz A, Burkali B, Menyhárt I. Mortality rate of acute heart attack in Zalaegerszeg micro-region. Results of the first Hungarian 24 hour acute myocardial infarction intervention care unit. Clin Exp Med J 2010, 4: 1-9.

62. Sigwart U, Puel J, Mirkovitch V, Joffre F, Kappenberger L. Intravascular stents to prevent occlusion and restenosis after transluminal angioplasty. $N$ Engl J Med. 1987; 316(12): 701-706.

63. Papp E, Késmárky G, Tóth K. Restenosis. in Atherosclerosis (Edit: Császár A.).Synergo. 2004: 179-186.

64. Buellesfeld L, Grube E. ABT-578-eluting stents. The promising successor of sirolimus- and paclitaxel-eluting stent concepts? Herz. 2004; 29(2): 167-170.

65. Collingwood R, Gibson L, Sedlik S, Virmani R, Carter AJ. Stent-based delivery of ABT-578 via a phosphorylcholine surface coating reduces neointimal formation in the porcine coronary model. Catheter Cardiovasc Interv. 2005; 65(2): 227-232.

66. Garcia-Touchard A, Burke SE, Toner JL, Cromack K, Schwartz RS. Zotarolimuseluting stents reduce experimental coronary artery neointimal hyperplasia after 4 weeks. Eur Heart J. 2006; 27(8): 988-993.

67. Meredith IT, Ormiston J, Whitbourn R, Kay IP, Muller D, Popma JJ, Kay IP, Muller D, Popma JJ, Cutlip DE, Fitzgerald PJ; ENDEAVOR I Investigators. Fouryear clinical follow-up after implantation of the endeavor zotarolimus-eluting stent: ENDEAVOR I, the first-in-human study. Am J Cardiol. 2007; 100: 56-61. 
68. Fajadet J, Wijns W, Laarman GJ, Kuck KH, Ormiston J, Münzel T, Popma JJ, Fitzgerald PJ, Bonan R, Kuntz RE; ENDEAVOR II Investigators. Randomized, double-blind, multicenter study of the Endeavor zotarolimus-eluting phosphorylcholine-encapsulated stent for treatment of native coronary artery lesions: clinical and angiographic results of the ENDEAVOR II trial. Circulation. 2006; 114(8): 798-806.

69. Kandzari DE, Leon MB, Popma JJ, Fitzgerald PJ, O'Shaughnessy C, Ball MW, Turco M, Applegate RJ, Gurbel PA, Midei MG, Badre SS, Mauri L, Thompson KP, LeNarz LA, Kuntz RE; ENDEAVOR III Investigators. Comparison of zotarolimuseluting and sirolimus-eluting stents in patients with native coronary artery disease: a randomized controlled trial. J Am Coll Cardiol. 2006; 48(12):2440-2447.

70. Pinto Slottow TL, Waksman R. Overview of the 2006 Food and Drug Administration Circulatory System Devices Panel meeting on drug-eluting stent thrombosis. Catheter Cardiovasc Interv. 2007; 69(7): 1064-1074.

71. Pfisterer M, Brunner-La Rocca HP, Buser PT, Rickenbacher P, Hunziker P, Mueller C, Jeger R, Bader F, Osswald S, Kaiser C; BASKET-LATE Investigators. Late clinical events after clopidogrel discontinuation may limit the benefit of drugeluting stents: an observational study of drug-eluting versus bare-metal stents. $J$ Am Coll Cardiol. 2006; 48(12): 2584-2591.

72. Rocca HP, Kaiser C, Pfisterer M. Targeted stent use in clinical practice based on evidence from the BAsel Stent Cost Effectiveness Trial (BASKET). Eur Heart $J$ 2007; 28(6): 719-725.

73. Kenéz A, Németh Z, Motyovszki Á, Takács I, Lupkovics G. Our experience with Endeavor stent implantations. Card Hung 2008; 38: 217-220. 